\title{
https://helda.helsinki.fi
}

\section{The mitigating role of tax and benefit rescue packages for poverty and inequality in Africa amid the COVID-19 pandemic}

\section{Lastunen, Jesse}

UNU-Wider

2021-10-01

Lastunen, J , Rattenhuber , P , Adu-Ababio , K, Gasior , K, Jara , HX, Jouste , M , McLennan, D , Nichelatti , E , Oliveira , R C , Pirttilä , J , Richiardi , M \& Wright, G 2021' The mitigating role of tax and benefit rescue packages for poverty and inequality in Africa amid the COVID-19 pandemic ' WIDER Working Paper , no. 2021/148, UNU-Wider , Helsinki . https://doi.org/10.35188/UNU-WIDER/2021/088-7

http://hdl.handle.net/10138/337873

https://doi.org/10.35188/UNU-WIDER/2021/088-7

unspecified

publishedVersion

Downloaded from Helda, University of Helsinki institutional repository.

This is an electronic reprint of the original article.

This reprint may differ from the original in pagination and typographic detail.

Please cite the original version. 
WIDER Working Paper 2021/148

The mitigating role of tax and benefit rescue packages for poverty and inequality in Africa amid the COVID-19 pandemic

Jesse Lastunen, ${ }^{1}$ Pia Rattenhuber, ${ }^{1}$ Kwabena Adu-Ababio, ${ }^{1}$ Katrin Gasior, ${ }^{2,3}$ H. Xavier Jara, ${ }^{3}$ Maria Jouste, ${ }^{1,4}$ David McLennan, ${ }^{2}$ Enrico Nichelatti, ${ }^{1}$ Rodrigo C. Oliveira, ${ }^{1}$ Jukka Pirttilä, ${ }^{1,5,6}$ Matteo Richiardi, ${ }^{3}$ and Gemma Wright ${ }^{2}$

October 2021 
Abstract: This paper analyses the distributional effects of the COVID-19 pandemic and related tax-benefit measures in 2020 in a cross-country comparative perspective for five African countries: Ghana, Mozambique, Tanzania, Uganda, and Zambia. We first estimate the impact of the crisis on disposable incomes, how effects vary across the income distribution, and in how far tax-benefit policies stabilized earnings losses. We then evaluate the impact on income-based poverty and inequality and the contribution of discretionary tax-benefit policies in alleviating the shock. Our analysis shows modest increases in headcount poverty rates and inequality, and somewhat larger effects on the poverty gap due to lower relative earnings losses of the poor population at the early stage of the pandemic analysed here. We find very limited stabilizing power of tax-benefit policies overall and automatic stabilizers in particular. This illustrates gaps in coverage for the large informal sector and a general lack of income-related means-tested benefits. Except for the Emergency Social Cash Transfer in Zambia, discretionary tax-benefit policies adopted in response to COVID-19 have had limited impact. Pausing a large school feeding programme in Ghana during lockdown has in turn put additional pressure on households with school-age children.

Key words: COVID-19, income distribution, poverty, inequality, Africa

JEL classification: D31, E24, H24

Acknowledgements: The results presented here are based on the respective country models. The models are developed, maintained, and managed by UNU-WIDER in collaboration with the EUROMOD team at the Centre for Microsimulation and Policy Analysis (University of Essex), SASPRI (Southern African Social Policy Research Insights), and local partners in selected developing countries (Ethiopia, Ghana, Mozambique, Tanzania, Uganda, Zambia, Ecuador, and Viet Nam) in the scope of the SOUTHMOD project. We thank Michael Noble and Helen Barnes from SASPRI and participants at various conferences and seminars for valuable comments and suggestions. Earlier versions of this paper were presented at the African Tax Research Network's Webinar Series 2020, at the Institute for Employment Research online seminar, the $6^{\text {th }}$ joint Nordic Development Research Conference, the Development Studies Association's 'Unsettling Development' conference, the 17th Annual Conference of the East Asian Social Policy Research Network and 27th Annual Conference of the Foundation for International Studies on Social Security, the Ninth Meeting of the Society for the Study of Economic Inequality, the UNU-WIDER Development Conference and UNU-WIDER research retreat. Andy Sumner and Eduardo Ortiz-Juarez generously shared country-specific results from their work. The results and their interpretation presented in this publication are solely the authors' responsibility.

Note: file slightly edited on 7 October and 2 November 2021, in particular to add missing industry titles in three figures in Appendix C.

${ }^{1}$ UNU-WIDER, Helsinki, Finland; 2Southern African Social Policy Research Insights (SASPRI), Hove, UK; ${ }^{3}$ University of Essex, Colchester, UK; ${ }^{4}$ University of Turku, Finland; ${ }^{5}$ University of Helsinki, Finland; ${ }^{6}$ VATT Institute for Economic Research, Helsinki, Finland. Corresponding author: rattenhuber@wider.unu.edu.

This note has been prepared within the UNU-WIDER project SOUTHMOD - simulating tax and benefit policies for development Phase 2, which is part of the Domestic Revenue Mobilization programme. The programme is financed through specific contributions by the Norwegian Agency for Development Cooperation (Norad).

Copyright (C) UNU-WIDER 2021

UNU-WIDER employs a fair use policy for reasonable reproduction of UNU-WIDER copyrighted content-such as the reproduction of a table or a figure, and/or text not exceeding 400 words - with due acknowledgement of the original source, without requiring explicit permission from the copyright holder.

Information and requests: publications@wider.unu.edu

ISSN 1798-7237 ISBN 978-92-9267-088-7

https://doi.org/10.35188/UNU-WIDER/2021/088-7

Typescript prepared by Lorraine Telfer-Taivainen

United Nations University World Institute for Development Economics Research provides economic analysis and policy advice with the aim of promoting sustainable and equitable development. The Institute began operations in 1985 in Helsinki, Finland, as the first research and training centre of the United Nations University. Today it is a unique blend of think tank, research institute, and UN agency_providing a range of services from policy advice to governments as well as freely available original research.

The Institute is funded through income from an endowment fund with additional contributions to its work programme from Finland, Sweden, and the United Kingdom as well as earmarked contributions for specific projects from a variety of donors.

Katajanokanlaituri 6 B, 00160 Helsinki, Finland

The views expressed in this paper are those of the author(s), and do not necessarily reflect the views of the Institute or the United Nations University, nor the programme/project donors. 
The global COVID-19 pandemic has had a devastating impact on people's lives as well as on global and national economies. The pandemic-driven global recession has been the deepest since the Second World War and produced the strongest hit in per capita incomes since 1980 (Ohnsorge and Yu 2021; Ayhan Kose and Sugawara 2020). Developing countries are particularly exposed to the pandemic due to their weaker healthcare and welfare systems, risks of famine, volatile commodity prices, and low living standards. According to ILO (2020) lockdown measures affected an estimated 81 per cent of the world's workforce at the height of the crisis, poverty could increase depending on the poverty line, by half a billion people (Sumner et al. 2020), and Africa was hit by at least US $\$ 100$ billion in economic costs in 2020 (te Velde 2020). Moreover, the pandemic has affected inequality across several domains of life, including employment, health and family life, impacts that will likely persist in the long term (Blundell et al. 2020). ${ }^{1}$

Governments worldwide have taken various actions to address the immediate health crisis including lockdown measures, often combined with social policy measures to cushion lockdownrelated income losses of households. ${ }^{2}$ In the developing world, measures to mitigate the effects on poverty and inequality have included various forms of income support, from food baskets to topping up existing means-tested benefits or introducing new temporary benefits, along with tax deferrals and waivers. At the same time, governments in developing countries are confronting the crisis operating in a highly constrained fiscal space. The situation could worsen considerably depending on how long the crisis protracts and how successful governments are in managing the pandemic. A better understanding of the effects of the COVID-19 pandemic and related policy measures on households is, therefore, both timely and necessary to support developing country policy makers in navigating the crisis. To this end, it is critical to distinguish between the economic impact of the COVID-driven economic downturn from the impact of tax and benefit policies.

This paper analyses the distributional effects of the COVID-19 pandemic and related tax-benefit measures in 2020 for five sub-Saharan African (SSA) countries: Ghana, Mozambique, Tanzania, Uganda, and Zambia. We estimate the impact of the crisis on earnings and show how earnings losses together with tax-benefit policies affected households' disposable income, and thereby poverty and inequality in each country. We also differentiate between the automatic stabilizing effect of the tax-benefit system that existed prior to the crisis and the effect of discretionary policy measures taken by governments in response to the crisis. The latter include emergency income support measures and tax waivers but also the pausing of existing social protection schemes as a consequence of lockdowns and social distancing policies. The five countries analysed make for an interesting comparison as they are all characterized by a large informal sector and low social protection coverage, but are different in the scope and nature of tax-benefit measures taken in response to the crisis.

Our approach is similar to Avellaneda et al. (2021) who compare the short- and medium-term impact of the crisis across the Andean countries, and Cantó et al. (2021) who compare outcomes for Belgium, Italy, Spain, and UK during the first month of the crisis. Similarly, single-country studies from the developing world include Wright et al. (2021) for Indonesia, Barnes et al. (2021) for South Africa, and Jara et al. (2021) for Ecuador. While the first paper analyses quarterly changes and the latter two analyse the first few months of the pandemic, we compare the situation right

\footnotetext{
${ }^{1}$ See also Addison et al. (2020) for a discussion of the macroeconomic dimension of the pandemic.

${ }^{2}$ See FAO (2020) and Gentilini et al. (2020) for an overview of social protection and employment policies adopted in Africa.
} 
before the crisis, with the situation over the latter nine months of 2020. Lustig et al. (2020) provide estimates of the impact of lockdowns and expanded social assistance for emerging Latin American countries but abstract from potential tax-related measures. A host of studies for developed countries employ a similar methodology to ours for a single country with different time windows and underlying data, for example Brewer and Tasseva (2021) for the UK, Kyyrä et al. (2021) for Finland, and Christl et al. (2021) for Germany. Our estimates on the increase in poverty also relate to the work by Sumner et al. (2020) and Valensisi (2020) who forecast the number of people pushed into poverty by the pandemic in the developing world.

For our analysis we require (1) micro data reflecting households' income and labour market situation before and at the time of the crisis, and (2) detailed modelling of the countries' tax-benefit policies including COVID-related policy reforms during 2020. The major challenge in the first step is the lack of detailed, up-to-date micro data on households, including information on household characteristics and specifically earnings throughout the crisis. We reweight the data to capture any structural demographic changes, and proxy job loss in the micro data by allocating industry-level GDP shocks randomly across workers in each industry. As a sensitivity check, we model micro-level labour market transitions using survey data from the World Bank Phone Survey Uganda. For the second step we use select cross-country comparative tax-benefit microsimulation models from the SOUTHMOD model family (see Decoster et al. 2019). Based on the first two steps, we estimate different welfare measures in combination with decomposition techniques to differentiate between the distributional impact of the earnings shock and the role of tax-benefit policies.

Through different combinations of the two datasets and two tax-benefit systems, we explore the effects of different shocks on disposable income, poverty and inequality, holding everything else constant similar to a controlled experiment (Bourguignon and Spadaro 2006; Dolls et al. 2012). We assess how much the different tax-benefit systems stabilized disposable income following Dolls et al. $(2012,2020)$. To further distinguish the economic impacts of the policies from those of the crisis and associated lockdown measures, we follow the decomposition approach pioneered by Bargain and Callan (2010), extended by Paulus and Tasseva (2020), and most recently adapted to the case of Andean countries by Avellaneda et al. (2021).

Our results point to relatively modest increases of headcount poverty based on disposable income at the US\$1.9 international poverty line, with poverty increases ranging between 2.2 percentage points in Zambia and 0.3 percentage points in Tanzania. These findings are roughly in line with the results for SSA from the poverty forecasting literature. The poverty gap increases in a more pronounced manner in most countries, reflecting that a large share of the population was already below the poverty line before the crisis. The Gini coefficient of income inequality remained the same in Uganda and grew by 1.7 per cent in Mozambique, with other countries falling in between.

In all countries, the main driver of losses in disposable income was earnings losses, with the middle and top quartiles of the distribution experiencing larger relative reductions. Automatic stabilizers had a negligible effect in cushioning against income losses, operating mainly in the top quartile of the distribution. This finding is in line with Jara et al. (2021) and Avellaneda et al. (2021) who found similar results for the Andean countries. Unlike developed countries, developing countries have large informal sectors, low social protection coverage and means-tests of benefits that are often not income-based, meaning that households do not automatically become eligible for benefits in case of income shocks. Discretionary COVID-19-related policy measures cushioned some of the detrimental impacts in Zambia, and to a marginal extent in Mozambique. The case of Ghana illustrates how lockdown measures can hurt the delivery of ongoing social protection measures as pausing the large national school feeding programme has dwarfed the positive impact of other policy measures. 
Our study contributes to the literature in a number of ways. First, we add to the literature on COVID-related cross-country comparative analysis on the distributional impact of tax-benefit systems. While such studies already exist for European (Cantó Sanchez et al. 2021) and Andean countries (Avellaneda et al. 2021), to the best of our knowledge, our study is the first cross-country comparative study for Africa analysing in detail the cushioning impact of tax-benefit policies for incomes, poverty, and inequality.

Second, we provide a detailed analysis of the limited role of automatic stabilizers in African countries, which poses a significant challenge for policy makers in times of crisis. After the 2008 financial crisis, the role of fiscal policies to mitigate the negative impact of crises has gained importance and attention. However, most of the literature concentrates on developed countries (see amongst others Alesina and Giavazzi 2013; Auerbach and Feenberg 2000; Dolls et al. 2012; Dolls et al. 2020; Kniesner and Ziliak 2002; Leventi and Picos 2019; McKay and Reis 2016; Paulus and Tasseva 2020). Evidence on how African countries fare in terms of the power of their redistributive systems in general, and in how far they are prepared to cope with shocks, is limited (Bargain et al. 2021; Gasior, Leventi, Noble et al. 2021; Devarajan et al. 2013). We address this gap in the literature by estimating how automatic stabilizers operated across the income distribution of five African countries during the crisis, and discuss why their redistributive power is so limited.

Third, we analyse how far the discretionary tax-benefit measures taken by some governments in response to the crisis alleviated the shock to households, modelling the most significant programmes for Ghana, Mozambique, and Zambia. Barely any notable measures were adopted in Uganda and Tanzania in 2020, and as a result none incorporated in the modelling.

Fourth, we provide an estimate of how poverty and inequality based on disposable income changed in the first year of the pandemic in five low-income and lower-middle-income economies in SSA, complementing the regional poverty forecasts (based on distance above the poverty line) by Sumner et al. (2020), Valensisi (2020) and others. With the exception of Avellaneda et al. (2021), our analysis also differs from other studies using similar methodologies as we do not focus on the immediate, short-run impact of the crisis in the first month(s) of the crisis but instead look across the combined nine pandemic months of 2020.

The remainder of the paper is structured as follows. Section 2 describes the dynamics of the COVID-19 outbreak in 2020, countries' economic situation and tax-benefit system going into the crisis, and how countries responded to the crisis in terms of lockdown and tax-benefit policies in 2020. Section 3 discusses data and methodology, including the respective microsimulation models, welfare measures and decomposition methods employed. Section 4 discusses results, analyses the role of the tax-benefit system in buffering the adverse impact of the crisis, and closes with a sensitivity analysis. Section 5 concludes.

\section{COVID-19 and government response in 2020}

\subsection{The development of the pandemic in 2020}

Most African countries reported their first COVID-19 case on almost the same date in March 2020. They also exhibit similar trends over time in terms of cases and deaths reported, with the peak of the first wave in summer 2020 (with the exception of Tanzania for which no data are available), the peak of the second wave around February 2021 (Figures A1 and A2 in Appendix A), and the third, by far most severe wave taking place at the time of writing in late summer 2021. However, the severity of the impact of COVID-19 in terms of cases and deaths reported is not homogeneous across time and space. Out of the countries analysed, Zambia is by far the most and 
Ghana the least affected country. After the onset of the second wave in October 2020, caseloads for Uganda grew at a faster pace. As the second wave took off further in other countries as well, Uganda and Mozambique reported similar numbers, sitting in between Zambia and Ghana, with Zambia again reporting by far the highest numbers. That said, the epidemiological situation in the countries studied here appears to have been less severe in 2020 than what has been observed in many other parts of the world, and in other African countries, such as South Africa and Namibia (Ritchie et al. 2020).

The debate on why overall the impact of the pandemic in SSA is lower in terms of confirmed cases and deaths is ongoing among epidemiologists. Potential factors brought up include favourable demographics, the lack of long-term care facilities, cross-protection from local circulating coronaviruses, and limited testing capacities. South Africa may be considered an exception in several of these dimensions, which could help explain why the country is considerably worse hit than many of its peers. ${ }^{3}$ Regardless of these considerations, the numbers for 2020, our period of analysis chosen due to the availability of data, reflect the early days of the pandemic and are clearly dwarfed by the magnitude of the second and third waves in 2021. In the light of the emerging epidemiological figures for 2021, slow vaccination campaign rollouts and the fast-changing nature of the virus, the prospects for 2021 and beyond appear bleak.

\subsection{Economic situation leading up to the crisis and contraction of the economy in 2020}

Since the turn of the millennium up until 2010, the economies of all countries studied grew at GDP growth rates of at least 4 per cent and often above 5 per cent (World Bank 2021a). Towards the end of the 2010s growth became more subdued in Zambia and Mozambique with growth rates below 4 per cent, while in Ghana and Uganda growth was picking up again at above 5 per cent after a small dent. In Tanzania growth rates had stayed above 5 per cent since 2013. Poverty rates according to national definitions and on an internationally comparative basis had remained relatively stable since 2010 across countries (World Bank 2021b). Since 2000, inequality measured by the Gini index-based consumption remained largely constant for Uganda (57 in 2017) and increased for Ghana (58 in 2017) and Mozambique (59 in 2015) (UNU-WIDER 2021a). With the exception of Zambia, tax-to-GDP ratios increased slowly across countries between 2000-19 from below 8 per cent to above 20 per cent in Mozambique and above 10 per cent in the other four countries studied (UNU-WIDER 2021b). This development was mainly driven by direct taxes and less so by indirect taxes. By contrast, Zambia's tax-to-GDP ratio started out at 17 per cent in 2000 and has largely remained constant until 2019.

While at the time of writing there is very limited or no micro-level data available for 2020 in the countries analysed (see Section 3 for more information), comparing 2020 GDP figures with preCOVID-19 trends provides initial evidence on the severity of the shocks to the economy (see Figures C1-C5 in Appendix C). Our estimates show a mixed picture of economic downturn across countries. While GDP in 2020 lagged substantially behind its pre-COVID trend in Zambia (-7.7 per cent) and Uganda (-6.6 per cent), the damage was more limited but still substantial in Mozambique ( -5.8 per cent) and Ghana (-4.7 per cent). For the economy as a whole GDP in Tanzania barely deviated from its pre-COVID trend in 2020 yet some sectors are still affected notably.

\footnotetext{
${ }^{3}$ While there is concern on how accurate the reported numbers are and whether they might not be underestimated, the general patterns are less subject of debate. Alternative data sources for the countries analysed, such as from the Economist Excess Death Tracker are either scarce or do not exist. For a non-technical overview of the debate, refer to this recent article in The Conversation.
} 
Some patterns observed for specific industries also hold across countries: The service sector, and notably accommodation and food services, are consistently amongst the hardest hit industries. For Ghana we estimate that economic activity in the sector was 37 per cent lower than expected based on pre-pandemic trends. Manufacturing also takes a blow but, except for Mozambique, is not amongst the hardest hit sectors. While mining contracted in Ghana and Uganda, the sector experienced a positive shock in Zambia. The picture is also mixed for professional, scientific, and technical activities, owing partly to different industry categories used across countries, along with varying employment patterns. In Uganda, for example, professional, scientific and technical activities experienced the greatest trend decline at 53 per cent. This sector, which however only covers 2.5 per cent of Ugandan workers, includes a wide variety of occupations and activities, including those that are particularly vulnerable to lockdown measures and customers avoiding crowds, such as street vendors. Public administration is among the least impacted sector in all countries except for Zambia where it belongs to the most affected. The education sector suffered considerably in Uganda and Zambia but not in Ghana where teachers remained employed as schools were closed for most of 2020.

By contrast, agriculture did not suffer notably in the five countries, and in some cases grew-in particular in Mozambique that experienced an excellent agricultural year (Club of Mozambique 2021). Considering the large shares of the population engaged in agriculture in the countries analysed, and the more limited impact of lockdown measures on farming activities, farming likely cushioned some of the adverse effects of the pandemic. At the time of writing the latter conjecture cannot be verified for each country analysed due to data limitations. Yet, micro data from the World Bank Phone Surveys for Uganda confirm that the share of households engaged in farming has increased since the start of the crisis, a pattern also found for Ethiopia, Malawi and Nigeria (World Bank 2021d).

In terms of the economic shock, Tanzania stands out with only half of its industries falling behind pre-COVID GDP trends in 2020. Unsurprisingly, the hardest hit industry in the country was the accommodation and restaurant sector that relies heavily on tourism.

\subsection{Tax-benefit systems and governments' response to the pandemic}

The tax-benefit systems in place in Ghana, Mozambique, Tanzania, Uganda, and Zambia before the pandemic are characterised by personal income tax and social security systems covering a rather small share of the population due to the large informal sector. Similarly, each country levies a presumptive tax or similar on small business turnover, along with VAT and excise policies. While all countries' tax-benefit systems share these main tenets in terms of tax or quasi-tax policies, the exact design of each of these policies varies widely. Social protection in terms of cash benefits in Ghana, Mozambique, Tanzania, and Zambia are dominated by programmes that target recipients largely based on proxy means tests or categorical targeting, in the case of Mozambique with elements of an income means test. In Uganda, the senior citizen grant is the main social protection programme. For more details on the different countries' tax-benefit systems, refer to the respective SOUTHMOD country reports. ${ }^{4}$ Gasior, Leventi, Noble et al. (2021) and Bargain et al. (2021) provide further insights into how the redistributive power of these systems compare across countries.

When the COVID-19 pandemic took hold in March 2020, governments were confronted with difficult choices about whether and when to implement lockdown measures in an environment where the vast majority of people relies on generating a continuous income flow, has little or no

\footnotetext{
${ }^{4}$ The most recent country report for Ghana is Adu-Ababio et al. (2021), Castelo et al. (2020) for Mozambique, Leyaro et al. (2021) for Tanzania, Waiswa et al. (2020) for Uganda, and Nakamba-Kabaso et al. (2020) for Zambia.
} 
private savings to rely on, the government's fiscal space is highly constrained, and social protection programmes are often (partly) funded by international donors. While all countries studied initially enacted some kind of lockdown measures in March 2020, policies diverged in the following months (see Appendix B). Most countries did retain varying restrictions, including limits on gatherings, (partial) closures of schools, workplaces and public transport, and restrictions on people's movements. Tanzania however took a different path. The government initially announced school closures and banned all sporting activities, followed by border closures in April 2020. Yet, from May onwards, the country started to taper lockdown measures, including the lifting of quarantine requirements for passengers arriving from international flights. Tanzania also stopped reporting and tracking cases (Reporters Without Borders 2020). ${ }^{5}$ In all other countries analysed, initial measures were either maintained or tightened, or measures fluctuated around the level of stringency of the initial lockdown over the course of the year (Hale et al. 2021).

Apart from deciding on lockdown measures, governments were also confronted with the need to decide whether and if so which discretionary policy measures to introduce to soften the blow of the crisis, on top of the potential support provided by the existing tax-benefit systems. ${ }^{6}$ In Section 3.3, we discuss in detail the discretionary tax-benefit policies relevant to household incomes that were enacted in each country and how we model them in our analysis. In general, the magnitude of policy response varies significantly across countries, with Tanzania being the only country not enacting any discretionary tax-benefit measures in response to the crisis. Across the other countries several policy initiatives were considered, some of which were enacted in 2020 . While some were rolled out quickly, others were delayed or still under discussion by the end of 2020 (also see Gentilini et al. 2020). ${ }^{7}$ Our analysis therefore captures the countries' initial policy response to the early, potentially less severe, stages of the crisis.

In terms of social protection, Zambia, Mozambique, and to a limited extent Ghana, scaled up existing social protection programmes by increasing benefit amounts or the number of beneficiaries. Some additional measures such as the distribution of food baskets and face masks were introduced in the early days of the pandemic but were often temporary and came with little targeting at the poor. School closures in Ghana and Zambia also implied unintended negative effects as the school feeding schemes in place in public schools were halted and families had to supply meals to their children that would usually have been provided by the government.

Other measures common across countries aiming to alleviate pressures on households related to (partly) waiving household's utility costs. All countries, except for Tanzania, also offered some form of tax payment deferrals. Waivers of tax payments were rare with the exception of Ghana, which exempted frontline and medical service workers from personal income tax for seven months in 2020. Many countries also offered a VAT waiver on medical supplies critical for combatting the pandemic and/or staple foods, along with support policies to small or medium-sized firms.

\footnotetext{
${ }^{5}$ See a discussion of the potentially harmful mid- to long-term economic impacts of the Tanzanian government's handling of the COVID-19 pandemic under its late President Magufuli published in February 2021 in a blog post by the Council on Foreign Relations (Council of Foreign Affairs 2021).

${ }^{6}$ See Gentilini et al. (2020) for an excellent and regularly updated overview on social protection measures taken across the world. For our analysis we gathered more detailed information together with our local partners in each country.

${ }^{7}$ Data on the state-led policy responses are also being gathered by a number of other organizations, including ODI, the Social Protection Responses to COVID-19 Task Force, the OECD database on tax policy responses to COVID19 by country, the University of Oxford's Government Response Tracker, the World Bank and UNICEF's live document on social protection and job responses to COVID-19. In addition, the World Health Organisation is publishing regular situation reports, and the ILO has been issuing a regular note since early 2020 .
} 


\section{Data and methodology}

In this section we first discuss the data underlying the models, how we update the data to account for changes in the population, labour market and prices prior to the pandemic, and how we adjust the data to reflect the COVID-19 shocks to household incomes. Next, we provide more information on the tax-benefit microsimulation models and how we model the policy environment during the pandemic. Finally, we discuss the methodology used to analyse the distributional impact of the crisis on household incomes and the decomposition technique applied to separate income shocks from tax-benefit related effects.

\subsection{Data and reweighting procedures}

SOUTHMOD models are all based on nationally representative household surveys, usually conducted every few years. For each country analysed, we use the latest available survey wave (see Table 1). The surveys contain information on household incomes, including labour and non-labour income incomes, and information on individual household members' characteristics and the household itself. The surveys also include detailed expenditure modules. For more information, refer to each model's most recent country report. ${ }^{4}$

Table 1: Data sources and models used

\begin{tabular}{|c|c|c|c|c|c|}
\hline & Ghana & Mozambique & Tanzania & Uganda & Zambia \\
\hline Dataset and wave & $\begin{array}{l}\text { Ghana Living } \\
\text { Standard Survey } \\
\text { (GLSS 7), } 2017\end{array}$ & $\begin{array}{l}\text { Inquérito ao } \\
\text { Orçamento } \\
\text { Familiar (IOF), } \\
\text { 2014-15 }\end{array}$ & $\begin{array}{l}\text { Tanzania } \\
\text { Household Budget } \\
\text { Survey (HBS), } \\
\text { 2017-18 }\end{array}$ & $\begin{array}{l}\text { Uganda National } \\
\text { Household Survey } \\
\text { (UNHS), 2016-17 }\end{array}$ & $\begin{array}{l}\text { Zambia's Living } \\
\text { Conditions } \\
\text { Monitoring Survey } \\
\text { (LCMS), } 2015\end{array}$ \\
\hline $\begin{array}{l}\text { Population data } \\
\text { used for re- } \\
\text { weighting }\end{array}$ & $\begin{array}{l}\text { World } \\
\text { Development } \\
\text { Indicators, World } \\
\text { Bank (projections) }\end{array}$ & $\begin{array}{l}\text { The National } \\
\text { Institute of } \\
\text { Statistics, } \\
\text { Mozambique } \\
\text { (projections) }\end{array}$ & $\begin{array}{l}\text { Tanzania National } \\
\text { Population } \\
\text { Projections Report, } \\
\text { National Bureau of } \\
\text { Statistics, } 2018\end{array}$ & $\begin{array}{l}\text { Uganda Bureau of } \\
\text { Statistics } \\
\text { (projections) }\end{array}$ & $\begin{array}{l}\text { World } \\
\text { Development } \\
\text { Indicators, World } \\
\text { Bank (projections) }\end{array}$ \\
\hline $\begin{array}{l}\text { Labour market data } \\
\text { used for re- } \\
\text { weighting }\end{array}$ & - & $\begin{array}{l}\text { Number of civil } \\
\text { servants (MTSS } \\
\text { Boletim Estatistico, } \\
\text { 2015-17) }\end{array}$ & $\begin{array}{l}\text { Economic status, } \\
\text { occupation, } \\
\text { formality, and civil } \\
\text { servants (LFS, } \\
\text { 2014) }\end{array}$ & - & $\begin{array}{l}\text { Economic status, } \\
\text { occupation, } \\
\text { formality, and civil } \\
\text { servants (LFS } \\
\text { 2017-19) }\end{array}$ \\
\hline $\begin{array}{l}\text { Industry-level GDP } \\
\text { data used to } \\
\text { estimate income } \\
\text { shocks }\end{array}$ & $\begin{array}{l}\text { GDP at constant } \\
2013 \text { prices by } \\
\text { economic activity } \\
\text { (Ghana Statistical } \\
\text { Service, May 2021) }\end{array}$ & $\begin{array}{l}\text { Quarterly GDP at } \\
\text { constant } 2014 \\
\text { prices by industry } \\
\text { (National Institute } \\
\text { of Statistics, } \\
\text { Mozambique, } \\
\text { Publication of } \\
\text { National Accounts } \\
\text { IV for Q4/2020, } \\
\text { February 2021) }\end{array}$ & $\begin{array}{l}\text { GDP at } 2015 \\
\text { prices by economic } \\
\text { activity; } 2020 \text { Q4 } \\
\text { predicted based on } \\
2017-19 \text { Q4 GDPs } \\
\text { (Tanzania National } \\
\text { Bureau of } \\
\text { Statistics, } \\
\text { December 2020) }\end{array}$ & $\begin{array}{l}\text { Quarterly GDP at } \\
\text { constant 2016/17 } \\
\text { prices up to } \\
\text { Q4/2020 } \\
\text { (Q2/2020-21 in } \\
\text { national notation; } \\
\text { Uganda Bureau of } \\
\text { Statistics, National } \\
\text { Accounts, March } \\
\text { 2021) }\end{array}$ & $\begin{array}{l}\text { Quarterly gross } \\
\text { value added by } \\
\text { industry at constant } \\
2010 \text { prices } \\
\text { (Zambia Statistics } \\
\text { Agency, Monthly } \\
\text { Bulletins up to vol. } \\
217, \text { April 2021) }\end{array}$ \\
\hline $\begin{array}{l}\text { SOUTHMOD } \\
\text { model and version }\end{array}$ & GHAMOD v2.4 & MOZMOD v2.7 & TAZMOD v2.2 & UGAMOD v1.6 & MicroZAMOD v2.6 \\
\hline
\end{tabular}

Source: see text.

Each survey was carried out several years before the COVID-19 pandemic. We therefore reweight the original data, creating counterfactual datasets reflecting the demographic situation right before the pandemic started (March 2020). In the first step, we account for structural demographic changes of the population in terms of gender and age in each country (see Table 1 for data sources used). For Mozambique, Tanzania and Zambia we also update the labour market profiles (see Table 1 for data sources used). For the other countries, where no suitable information on the current labour market profile is available, we assume that the labour market profile had remained 
unchanged since the collection of the original data. In the following we refer to these reweighted datasets as our pre-crisis or baseline datasets. For a detailed account of the steps undertaken in the reweighting procedure, refer to the technical note by McLennan (2021).

In addition to the demographic and labour market re-weighting explained above, we also apply standard uprating adjustments to incomes and expenditures in the original datasets (please refer to each model's country report for the specific indices used). This adjustment accounts for changes in price levels between the time of original data collection and 2020.

\subsection{Adjusting earnings to the COVID-19 crisis situation}

We expect the pandemic to reduce earnings in the countries under consideration due to various reasons. Government-mandated restrictions and lockdown measures reduced international trade and tourism, and voluntary reduction of consumption and mobility figure as some of the most apparent explanations. To account for these adverse effects on individuals' and ultimately households' earnings, we created a dataset reflecting shocks to individuals' earnings (employees and self-employed, referred to as the crisis data below. We concentrate on earnings as the main source of income and abstract from detrimental income effects the crisis might have on other types of income such as pension income, capital income, and remittances. At the time of writing there is little information on how these other types of incomes have been affected household incomes in the countries analysed. At the same time for certain incomes such as pensions the impact of the crisis might not be felt immediately in 2020 but in the longer run.

First, we calculated for each industry in each country the deviation of real GDP in 2020 from its pre-COVID-19 2017-19 trend, using annual, industry-level GDP data (again, see Table 1 for the data sources and Appendix $C$ for more details). Second, we randomly distributed the negative sectoral shocks to individual level earnings by adjusting earnings in the pre-crisis baseline dataset. ${ }^{8}$ For that purpose we assigned random workers in each sector to unemployment with zero income until the overall reduction in labour income matched the GDP shock for the same sector (for more details, see the dedicated technical notes by Oliveira et al. 2021 and Lastunen 2021). This last step resulted in the so-called crisis dataset.

A competing and in fact our preferred approach would have been to model labour market transitions based on micro data, as has been done in a similar context recently by various authors, including Jara et al. (2021) for Ecuador, Barnes et al. (2021) for South Africa, Christl et al. (2021) for Germany, and Cantó et al. (2021) for Belgium, Spain, and UK. In a separate technical note (Oliveira et al. 2021), we discuss a labour market transition model for Uganda, imputing income losses based on micro data from World Bank Phone Survey for Uganda (World Bank 2021c). This method allows for a more detailed allocation of earning shocks within sectors and across the income distribution. Instead of randomly allocating workers to unemployment, individuals are more likely to lose some of their earning if they possess characteristics that correspond to a higher probability of losing income based on characteristics such as age, sex, education, and working in the formal sector. Unfortunately, such micro data was not available for most countries in this study, with the exception of Uganda, which is why we used random allocation for all countries to ensure the comparability of our results. We nevertheless used the results from the labour market transition method for Uganda to assess the sensitivity of our findings to the method used (Section 4.3).

\footnotetext{
${ }^{8}$ We concentrate here on negative sectoral GDP shocks and do not adjust earnings for positive sectoral GDP shocks. We consider the time of analysis to be too short for significant wage increases given wage rigidities.
} 


\subsection{Tax-benefit policy measures in response to the crisis and implementation}

We used the tax-benefit microsimulation models developed for Ghana (GHAMOD), Mozambique (MOZMOD), Tanzania (TAZMOD), Uganda (UGAMOD) and Zambia (MicroZAMOD) to analyse the role of the tax-benefit system that pre-existed the crisis and the impact of discretionary tax-benefit policies taken in response to COVID-19 (refer to Table 1 for the specific model versions used for the analysis). For the purpose of our analysis we incorporated the various COVID-related tax-benefit policies into the models in addition to any policy changes that were implemented in 2020 regardless of COVID-19.

In normal times governments usually apply changes and reforms to their tax-benefit systems once per year, and rules tend to apply throughout the entire (financial or calendar) year. The standard SOUTHMOD models therefore employ a point-in-time perspective referring to 30 June $^{9}$ of the respective year that is being modelled (see the SOUTHMOD modelling conventions for more details; UNU-WIDER 2021c).

In such a framework, modelling COVID-19-related policies poses a challenge due to the ad hoc introduction and/or relatively short-term nature of many of the measures enacted. All COVIDrelated policies were effective only after the pandemic broke, many of them came into effect only a few months after that, and some were limited to last for only a few months in 2020. For a proper reflection of the fast-changing situation in 2020, we adopt a full-year perspective in our analysis. Practically, this entails simulating benefits and tax rules only for the months when they actually applied, which requires scaling them relative to a year (refer to the technical note by Gasior, Barnes, Jouste et al. 2021 for a detailed description).

Our simulations do not capture all measures taken for mainly three reasons. First, we do not simulate deferrals of tax (penalty) payments as we do not consider those to become permanent and thus do not treat them as a waiver. Second, our modelling is limited by the level of detail available from the underlying micro data, and how precise tax-benefit rules are formulated. Third, while we consider small household businesses and the self-employed in our simulations, most of the schemes enacted for those groups either remain opaque in terms of their exact implementation or the micro data does not include detailed enough information regarding business activities to allow proper modelling. The results furthermore present the design effects of the tax-benefit systems if the system were perfectly implemented, thus assuming full take-up of the newly introduced benefits and that beneficiaries receive the full amount specified in the rules.

Table 2 summarizes the main COVID-19-related tax-benefit policies incorporated into the models (see Appendix D for a detailed breakdown of measures and modelling). ${ }^{10}$ Overall, Ghana, Mozambique and Zambia implemented a more comprehensive package of discretionary policies responses to the crisis compared to Uganda, whereas Tanzania took no measures of significance. Apart from the COVID-19-related measures the models include the modelling of tax-benefit systems as they were in place when the crisis hit.

\footnotetext{
${ }^{9} 1$ July for Uganda and Tanzania because their financial years end on 30 June.

${ }^{10}$ The information has been collected by each SOUTHMOD national team, often in conversation with government and its agencies, but also donors. In as far as available we provide sources and weblinks for the information.
} 
Table 2: Overview of major COVID-19-related policies included in the analysis, by country

\begin{tabular}{|c|c|c|c|c|}
\hline Ghana & Mozambique & Tanzania & Uganda & Zambia \\
\hline $\begin{array}{l}\text { - Food rations for LEAP } \\
\text { beneficiaries } \\
\text { - Utility tariffs reliefs } \\
\text { - Income tax waiver for } \\
\text { medical and frontline } \\
\text { staff } \\
\text { - Limitations to school } \\
\text { feeding due to school } \\
\text { closures }\end{array}$ & $\begin{array}{l}\text { - Top-up of existing, } \\
\text { unconditional cash } \\
\text { transfer, the Basic } \\
\text { Social Subsidy } \\
\text { Program } \\
\text { - Utility tariff reliefs }\end{array}$ & $\begin{array}{l}\text { Barely any } \\
\text { policies } \\
\text { adopted; none } \\
\text { modelled. }\end{array}$ & $\begin{array}{l}\text { Few policies } \\
\text { adopted; none } \\
\text { modelled. }\end{array}$ & $\begin{array}{l}\text { - Top-up of existing, } \\
\text { unconditional cash } \\
\text { transfer (Social Cash } \\
\text { Transfer) via the } \\
\text { Emergency Social } \\
\text { Cash Transfer } \\
\text { - Limitations to school } \\
\text { feeding due to school } \\
\text { closures }\end{array}$ \\
\hline
\end{tabular}

Source: see Appendix D.

Specifically, our analysis incorporates tax-benefit policy measures related to COVID-19 in each country in the following manner (refer to Appendix D for a detailed breakdown of measures and their modelling):

Ghana: In the initial stages of the pandemic, Ghana supplied food rations to vulnerable households which at the time benefited from LEAP transfers (for 21 days in lockdown areas, starting on 9 April 2020) which we model as a top-up to LEAP recipients. ${ }^{11}$ Other policies included a full waiver for water costs for nine months, a full waiver for electricity costs for the poorest, and a 50 per cent waiver for electricity costs for all other consumers. ${ }^{12}$ Simulation is only partly possible as the data does not specify monthly energy use. Additionally, individuals in Ghana whose employer is providing frontline and medical services became exempted from paying personal income tax between May and December 2020. ${ }^{13}$

While not a deliberate policy change, school closures carried major implications for one of the most important benefits in the country, school feeding in public schools. When schools closed during the pandemic, the in-kind Home-Grown School Feeding programme for pre-high school students stopped between 30 March and December 2020. However, meals were again provided later in the year to final-year junior and senior high school students (from 9 April for three months) ${ }^{14}$ as well as for second-year senior high school and junior high school students (24 August until 18 September) in both public and private schools. ${ }^{15}$ In our simulations, we treat the nonprovided meals to children in public schools as lost income for households, assuming that households had to use their own resources to feed the children while they were unable to attend school. We proxy the cost for the household with the same amount per meal as the monetized value of a meal in the school feeding programme.

Mozambique: The government bolstered the two most important social protection programmes in the country. Existing beneficiaries of the Basic Social Subsidy Program (BSSP) received an additional unconditional cash transfer equal to three months of the regular benefit. The Direct

\footnotetext{
11 Address to the Nation by President Akufo-Addo on Updates to Ghana's Enhanced Response to COVID-19, 9 April 2020.

12 Address to the Nation by President Akufo-Addo on Updates to Ghana's Enhanced Response to COVID-19, 9 April 2020.

13 Presidency of the Republic of Ghana, Update N.05: Measures Taken to Combat the Spread of the Coronavirus.

14 Address to the Nation by President Akufo-Addo on Updates to Ghana's Enhanced Response to COVID-19, 9 April 2020.

15 Presidency of the Republic of Ghana, Update N.15: Measures Taken to Combat the Spread of the Coronavirus.
} 
Social Support Program also saw a similar hike (which is not simulated due to data restrictions). ${ }^{16,17}$ Utility tariffs were substantially reduced for consumers which we partially simulate. ${ }^{18}$ Furthermore, we model the VAT exemption for sugar, cooking oil and soap.

Zambia: On 28 July 2020, Zambia enacted an Emergency Social Cash Transfer, which covers an additional cash transfer for households already receiving Social Cash Transfer ('vertical expansion'), and introduced a new benefit component for vulnerable households working in the informal sector ('horizontal expansion'). ${ }^{19}$ Due to data restrictions, only the vertical extension is modelled. The benefit amounts to 400 Kwachas (a bit less than US\$20) per household per month for six months, covering 22 districts.

Zambia also paused its Home-Grown School Feeding Program due to the closure of schools during the lockdown between 17 March and 28 September $2020 .{ }^{20}$ During this phase, children enrolled in public schools who would usually have received a meal at school did not benefit from the programme. Similar to Ghana, we model this as a forgone benefit to the household, decreasing the incomes of initially benefitting households by the monetized value of a school meal. We do not model the suspension of custom duties and VAT on medical supplies, waiver of tax penalties and interest on outstanding tax liabilities granted to businesses, as the data does not allow to identify those goods.

Uganda took some minor measures such as the exemption of VAT on certain products relevant to fighting the pandemic, distribution of face masks to the population, and food relief to the vulnerable. None of these measures can be simulated in a satisfactory manner as the data and rules lack the necessary level of detail. Yet, none of these policies held much potential in substantially boosting household incomes.

In Tanzania no noteworthy tax-benefit measures were adopted in 2020 and consequently none were incorporated in the models.

\subsection{Measuring the impact of the crisis and the cushioning effect of tax-benefit systems}

The question of how effective tax-benefit systems have been in cushioning the population from the COVID-19 shock cannot be answered with a single indicator. We therefore approach the question from three different angles. First, we focus on how incomes, poverty, and inequality have changed due to the crisis in 2020. Second, we assess the extent to which tax-benefit systems managed to stabilize incomes on average. Third, we look in more detail into the policy effects and differentiate between the role of automatic stabilizers (i.e. the pre-crisis tax-benefit system) and the effectiveness of the COVID-related discretionary policy responses.

\footnotetext{
${ }^{16}$ For more details about BSSP, see: https://www.social-protection.org/gimi/RessourcePDF.action?id=57176. At the end of 2020, the government also enacted the Post Emergency - Direct Social Support Program (PASD-PE). The program targets low-income families not covered by the BSSP. Because most of the beneficiaries received the benefit in 2021, and due to lack of up-to-date data about this programme, we do not simulate it for 2020.

${ }^{17}$ Clientes da Electricidade de Moçambique, E.P. (EDM), 'Durante seis meses: EDM reduz tarifa de energia para mitigar efeitos da COVID-19', https://www.edm.co.mz/pt/website-mobile/article/not\%C3\%ADcia/durante-seismeses-edm-reduz-tarifa-de-energia-para-mitigar-efeitos.

${ }^{18}$ The reduction for utility fees for electricity is simulated. However, the reduction in fees for water is not simulated as it is not possible to distinguish between public and private water sources in the underpinning dataset.

19 Source: MCDSS (2021) COVID-19 Emergency Cash Transfers Fact sheet, supported by UNICEF, https://www.unicef.org/zambia/reports/covid-19-emergency-cash-transfers-brochure .

${ }^{20}$ Source: Zambia Institute for Policy Analysis and Research (ZIPAR).
} 
For cross-country comparable estimates, we use the PPP-adjusted US $\$ 1.90$ poverty line together with a per capita equivalence scale. Therefore, our results are not directly comparable with the national poverty and inequality benchmark values, as those are based on differing national poverty lines and equivalence scales (usually in the form of variations of calorie based scales).

\section{Comparing pre-crisis and crisis welfare measures}

Our analysis focuses on the following welfare measures: average household disposable income, income-based headcount poverty (FGT0) and poverty gap (FGT1), the Gini coefficient of income inequality, and the income stabilization coefficient. For each measure, we compare the baseline (pre-crisis) level to the COVID (crisis) situation.

Defining $y$ as pre-crisis gross market income, $t(y)$ as income tax and social security contributions, and $b(y)$ as government transfers, household disposable income in the pre-crisis baseline equals $D=y-t(y)+b(y)$. Similarly, crisis disposable income is defined as $D^{\prime}=y^{\prime}-t^{\prime \prime}\left(y^{\prime}\right)+$ $b^{\prime \prime}\left(y^{\prime}\right)$ where $y^{\prime}$ stands for crisis market income, $t^{\prime \prime}\left(y^{\prime}\right)$ for the income tax and social security contributions on crisis market income, and $b^{\prime \prime}\left(y^{\prime}\right)$ captures government transfers in the crisis scenario. ${ }^{21}$ Single quotation marks stand for the impact of the crisis and double quotation marks stand for reforms. The total difference $\Delta$ in welfare index I is then:

$$
\Delta=\mathrm{I} \underbrace{\left[\mathrm{y}^{\prime}-\mathrm{t}^{\prime \prime}\left(\mathrm{y}^{\prime}\right)+\mathrm{b}^{\prime \prime}\left(\mathrm{y}^{\prime}\right)\right]}_{\text {crisis scenario }}-\underbrace{\mathrm{I}[\mathrm{y}-\mathrm{t}(\mathrm{y})+\mathrm{b}(\mathrm{y})]}_{\text {pre-crisis scenario }}
$$

Figure 1: Simulation datasets and policy modelling resulting in three modelling scenarios

Simulation of disposable income based on

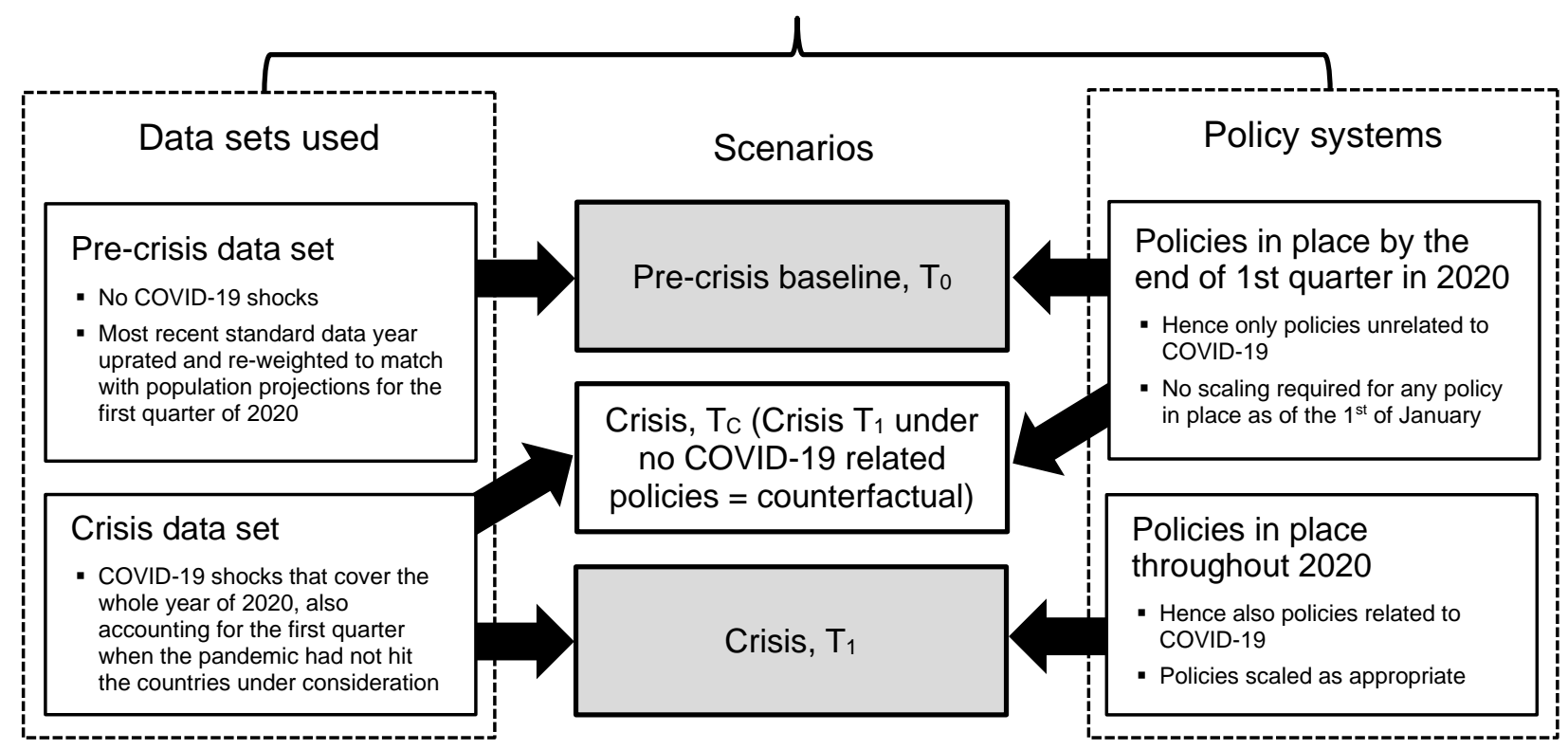

Source: authors' illustration.

\footnotetext{
${ }^{21}$ Market income is composed of labour, business, capital, property and other incomes, and in our analysis we restrict the shock to earnings by employees, the self-employed and farmers as the most important and often exclusive income source for the majority of the population.
} 
Welfare indices $I$ can be estimated based on the simulated distributions of disposable income in the pre-crisis and crisis scenarios. For the first step we compare mean incomes, poverty and inequality in the pre-crisis baseline scenario $\left(T_{0}\right)$ with the crisis scenario $\left(T_{1}\right)$, combining data and policy systems as depicted in Figure 1. The figure also shows a third, counterfactual scenario, $\mathrm{T}_{\mathrm{c}}$, explained in the decomposition section below.

\section{Income stabilization coefficient}

For the second step we follow Dolls et al. $(2012,2020)$ and calculate the income stabilization coefficient to measure how changes in market incomes translate into changes in household disposable income. The income stabilization coefficient $\tau^{I}$ for a given country is defined as:

$$
\tau^{I}=1-\frac{I\left[D^{\prime}\right]-I[D]}{I\left[y^{\prime}\right]-I[y]}
$$

whereby $I$ stands for the mean of the respective income distribution (disposable and market incomes) for scenarios $T_{0}$ and $T_{1}$. The higher the coefficient, the stronger the stabilization effect (or income insurance) and vice versa. For example, an $\tau^{I}$ equal to 0.15 implies that 15 per cent of the shock to market incomes is absorbed by the tax-benefit system. When average disposable income decreases more during the crisis than average market income, the coefficient turns negative. In practice, this can occur when social protection programmes that existed before the crisis cannot be delivered anymore due to the crisis and related lockdown measures.

\section{Decomposition of changes to the distribution of disposable income}

As a third step, we take a closer look at the tax-benefit system and dissect the contributions of automatic stabilizers and discretionary COVID-19-related policy responses in cushioning the shock. We employ the decomposition approach pioneered by Bargain and Callan (2010), extended by Paulus and Tasseva and most recently applied by Brewer and Tasseva (2020) for the UK and Jara et al. (2021) for Ecuador. Different from the income stabilization coefficient, which provides a measure of the average effect, this approach allows us to focus on the income distribution as a whole.

The decomposition approach requires simulating a third scenario $\left(\mathrm{T}_{\mathrm{C}}\right)$ that combines the crisis dataset with the tax-benefit system that excludes the COVID-19 response measures, as depicted in Figure 1. A step-wise comparison of the pre-crisis, crisis and counterfactual scenarios allows us to attribute the distributional impact of the crisis to the following three factors: (i) market income losses due to COVID-19, (ii) the automatic stabilizing role of the general tax-benefit system that pre-existed the crisis, and (iii) the additional impact of discretionary policy measures introduced related to the COVID-19 crisis. The latter category includes the specific support of the additional social protection benefits as well as the discontinuation of school feeding in public schools in Ghana and Zambia as described above.

For the decomposition, we start with $\Delta$, the total difference in welfare index, $I$, defined above. This difference can be decomposed into the contributions of the COVID-related benefits and other effects:

$$
\begin{aligned}
& \text { COVID-related policy changes (scenario } T_{1}-\text { scenario } T_{C} \text { ) } \\
& \Delta=\longdiv { \{ I [ y ^ { \prime } - t ^ { \prime \prime } ( y ^ { \prime } ) + b ^ { \prime \prime } ( y ^ { \prime } ) ] - I [ y ^ { \prime } - t ( y ^ { \prime } ) + b ( y ^ { \prime } ) ] \} } \\
& +\left\{I\left[y^{\prime}-t\left(y^{\prime}\right)+b\left(y^{\prime}\right)\right]-I[y-t(y)+b(y)]\right\} \\
& \text { Other effects (scenario } T_{C}-\text { scenario } T_{0} \text { ) }
\end{aligned}
$$


In the case of additively decomposable measures, such as the mean of a distribution, the latter term (other effects) can be split out into the contribution of changes in gross market income (including earnings) and the contribution of automatic stabilizers: ${ }^{22}$

$$
\begin{aligned}
\Delta= & \overbrace{I\left[y^{\prime}-t^{\prime \prime}\left(y^{\prime}\right)+b^{\prime \prime}\left(y^{\prime}\right)\right]-I\left[y^{\prime}-t\left(y^{\prime}\right)+b\left(y^{\prime}\right)\right]}^{\text {policy changes (scenario } \left.T_{1}-\text { scenario } T_{C}\right)}+\overbrace{\left\{I\left[y^{\prime}\right]-I[y]\right.}^{\text {earnings changes }} \\
& +\underbrace{\left\{I[t(y)]-I\left[t\left(y^{\prime}\right)\right]\right\}}_{\text {taxes and SICs as automatic stabilizers }}+\underbrace{\left\{I\left[b\left(y^{\prime}\right)\right]-I[b(y)]\right\}}_{\text {benefits as aut. stabilizers }}+\underbrace{\eta}_{\text {residual term }}
\end{aligned}
$$

\section{Impact of the crisis on incomes, poverty and inequality and the role of tax-benefit policies}

In this section we first show how disposable income was affected across countries, in terms of how far tax-benefit policies managed to stabilize incomes provided by the shock, and how automatic stabilizers performed relative to the emergency policy measures, at the mean of the distribution and across the income distribution. In a second step, we discuss how poverty and inequality estimated based on disposable income were affected and assess the role of COVIDrelated policies.

\subsection{Impact of the crisis on mean disposable income}

Table 3 compares mean disposable household incomes in international dollars before the crisis and during the crisis in 2020. Household disposable incomes decreased in all countries, with the largest income losses in Zambia and smallest in Tanzania (column A). The contained drop in Ghana can be explained by the negative sectoral GDP shocks being concentrated in parts of the economy that employ a relatively smaller share of the population. Overall, the decrease in household incomes is smaller than what has been found in studies for South Africa (Barnes et al. 2021) and the Andean region (Avellaneda et al. 2021), which can be partly explained by the relatively greater earnings shocks in those countries and the period of analysis.

The income stabilization coefficients show that tax-benefit policies did stabilize household disposable incomes in most countries, although sometimes at very low levels (column B). Stabilization is highest for Zambia where 21.5 per cent of the loss in market income is protected by the tax-benefit system, whereas the coefficient stands at 4.8 per cent in Tanzania, with Mozambique and Uganda sitting in between. Given that the overall shock estimated is not drastically different across countries, with the exception of Tanzania, this is a first indication that the magnitude of response of tax-benefit policies differed significantly across countries.

The negative stabilization coefficient for Ghana arises due to the discontinuation of the school feeding programme. With children out of school, and assuming that households did feed these additional meals paying with their own means, the decrease in household disposable incomes is estimated to be larger than the decrease in market incomes which results in a negative stabilization coefficient. Moreover, even though the government briefly re-initiated the feeding programmes for high school students and took other tax-benefit policies, their magnitude and scope were not strong enough to offset the negative impact of the pause in school feeding, the country's largest

\footnotetext{
${ }^{22}$ Applying the last step to non-additively decomposable measures such as poverty and inequality is challenging as one is left with a non-zero residual term, also see Paulus and Tasseva (2020) on the implications.
} 
social protection scheme. While Zambia's school feeding programme was also put on hold, it was paused for a shorter period of time and the discretionary policy measures more than made up for the benefits lost at the bottom of the distribution.

Table 3: Impact of COVID on mean disposable income, by country

Decomposition of total change

Total Income stabilization

change coefficient

$\begin{array}{ccc}\text { Effect of } & \begin{array}{c}\text { Effect of automatic } \\ \text { stabilizers }\end{array} & \begin{array}{c}\text { COVID-related } \\ \text { reduction in earnings }\end{array}\end{array}$

(A)

$\begin{array}{llrr}\text { Ghana } & -50.6^{\star \star \star} & -0.8 & +1.3^{\star \star \star} \\ \text { Mozambique } & (-1.92 \%) & & (+0.05 \%) \\ & -36.9^{\star \star \star} & +10.1 & +0.8^{\star \star \star} \\ \text { Zambia } & (6.97 \%) & & (+0.15 \%) \\ & -84.3^{\star \star \star} & +21.5 & +4.6^{\star \star \star} \\ \text { Tanzania } & (9.84 \%) & & (+0.53 \%) \\ & -8.8^{\star \star \star} & +4.8 & - \\ \text { Uganda } & (-0.85 \%) & & -\end{array}$

(C)

(D)

$+4.0$

$(+0.15 \%)$

$+3.2$

$(+0.61 \%)$

$+17.7$

$(+2.06 \%)$

$+0.5$

(+0.04\%)

$+7.5$

(+1.01\%)
(E)

(-2.12\%)

$-40.9$

(-7.73\%)

$-106.6$

(-12.44\%)

$-9.3$

(-0.89\%)

$-48.8$

(-6.53\%)

Note: the table presents estimates of the impact of the COVID-19 pandemic on mean incomes, shown in international dollars and derived based on harmonized equivalence scales in the respective countries in 2020. Column (A) shows the change in mean disposable income for individuals in the scenarios without and with shocks from COVID-19, i.e., the overall effects of the crisis. Across rows, the absolute change is shown for each country above (with statistical significance) and the corresponding percentage change below. The crisis scenario also accounts for COVID-related tax-benefit policy changes made in 2020. Column (B) shows the income stabilization coefficient. Columns (C), (D) and (E) show the independent effects of discretionary policy changes made during the crisis (with statistical significance), automatic stabilization of the tax-benefit system, and the COVID-induced earnings shock, respectively, again both in absolute and percentage changes. Statistical significance is based on bootstrapped standard errors after 200 replications. Significance levels indicated as * $p<$ $0.1,{ }^{\star *} p<0.05,{ }^{* \star *} p<0.01$.

Source: authors' elaboration using SOUTHMOD tax-benefit microsimulation models and survey data for the respective countries.

Decomposing the total change in mean disposable income (columns $\mathrm{C}$ through $\mathrm{E}$ ) reveals that the fall in disposable income largely reflects the earnings shock (column D) which accounts for between 0.9 per cent (Tanzania) to 12.4 per cent (Zambia) of the total shock to mean disposable income. Automatic stabilizers, thus the contribution of the tax-benefit system as it existed before the crisis, played a very limited role in containing the shock to disposable income (column D), contributing between 0 (Tanzania) and 2.1 per cent (Zambia). In Ghana, Mozambique and Zambia where governments took discretionary tax-benefit policy measures in response to the pandemic, these measures contributed against income losses, yet to quite limited extent. In Uganda, and to very little extent Tanzania, some policy measures were enacted that we cannot model sufficiently well due to data restrictions. Yet, given the information available on these measures it seems reasonable to assume that including them would not have changed the main results of our analysis.

\subsection{Impact of the crisis and tax-benefit policies along the income distribution}

In this subsection we look at how the different factors discussed above for mean disposable income behave across the household disposable income distribution (Figure 2 for Ghana, 
Mozambique and Zambia and Figure 3 for Tanzania and Uganda). For each country, we show (1) in the figure on the left, the decomposition of the relative change in mean disposable household incomes by income quartiles (similar to the analysis above for the mean), and (2) in the figure on the right, relative income changes solely due to the automatic stabilization properties of the taxbenefit system.

Across countries - with the exception of Ghana further discussed below-decreases in disposable income are more pronounced at the upper half of the pre-crisis distribution of household disposable income (white dot in left panels of Figures 2 and 3), measured in terms of relative income changes. The decrease for the top quartile ranges between 14 per cent in Zambia and less than 1 per cent in Tanzania. ${ }^{23}$

Figure 2: Decomposition of changes in mean disposable household income by quartile: Ghana, Mozambique, Zambia, 2020
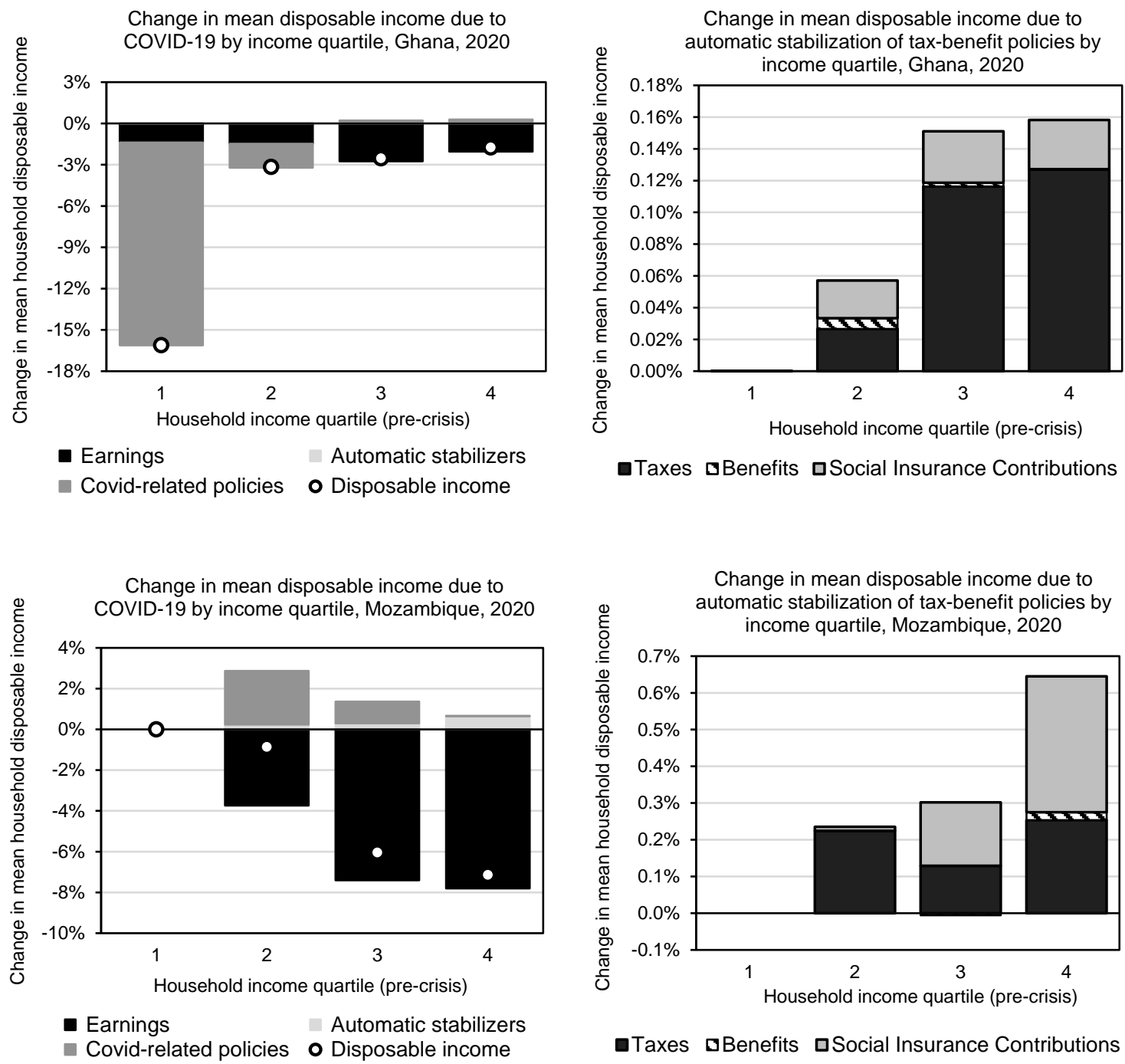

\footnotetext{
${ }^{23}$ In Mozambique household disposable incomes in the bottom quartile evaluate to zero as many households report no income (yet all households report non-zero consumption). We can thus not calculate the relative change in income for the bottom quartile. Nevertheless, COVID policies also raised incomes and thus increased consumption opportunities for this group of the population in absolute terms.
} 

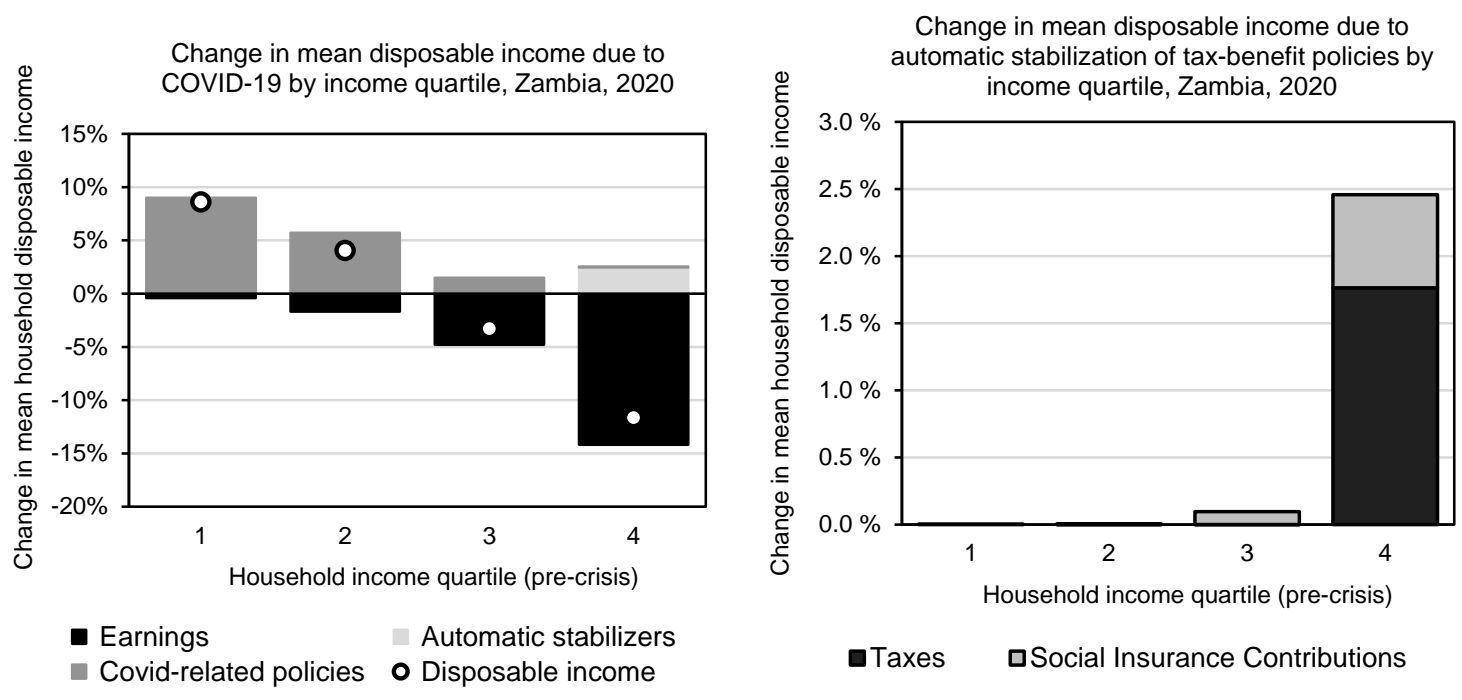

口Taxes $\quad$ GSocial Insurance Contributions

Note: the figures decompose the income shock from COVID-19 in Ghana, Mozambique and Zambia in 2020 into contributions from different sources. The figure on the left decomposes the shock on mean household disposable incomes into different components, namely: (i) Earnings losses resulting from the pandemic (black), (ii) the effects of COVID-related government policy changes (dark grey), and (iii) the automatic stabilization of the taxbenefit system (light grey). The net impact on disposable household income is presented by the white dots. The figure on the right decomposes the automatic stabilization of the tax-benefit system into (i) savings from reduced tax payments, (ii) savings from additional social benefits, and (iii) savings from social insurance contributions. In both figures, effects are shown separately for different income quartiles, derived from disposable household incomes in the pre-crisis scenario. All changes in income are based on per capita household disposable income.

Source: authors' elaboration using GHAMOD, the tax-benefit microsimulation model for Ghana, and the Ghana Living Standard Survey (GLSS 7, 2017); MOZMOD, the tax-benefit microsimulation model for Mozambique, and the Inquérito ao Orçamento Familiar survey (IOF, 2014-15); and MicroZAMOD, the tax-benefit microsimulation model for Zambia, and the Zambia's Living Conditions Monitoring Survey (LCMS, 2015).

The major driver for the pattern of shocks to disposable incomes for the African countries analysed here is the earnings shocks (dark bar in left panels of Figures 2 and 3). In all countries, the crisis affected earnings more in the top half of the income distribution. This pattern is similar to findings for South Africa and the Andean countries (Barnes et al. 2021; Avellaneda et al. 2021; Jara et al. 2021). For the countries analysed here, the finding reflects that a large share of households at the bottom of the distribution is economically active in agriculture, a sector less likely to be affected by lockdown measures (also see Appendix C). As illustrated by World Bank (2021d) households in SSA also seemed to have resorted to increase their agricultural activities, which might have served as an additional buffer. Patterns of earning shocks are clearly different for European countries, with most of the literature pointing to a relatively greater reduction of earnings at the bottom of the distribution (for example, Christl et al. 2021 for Germany; Figari and Fiorio 2020 for Italy; Canto et al. 2021 for Belgium, Italy, Spain, and UK).

Second, automatic stabilizers had a negligible effect in cushioning against income losses (light grey bar in left panels of Figures 2 and 3). Across countries, the stabilizers mainly worked (to a limited extent) for the top quartile of households, ranging from around 0.05 per cent in Tanzania to 2.5 per cent in Zambia. This result is similar to the findings for the Andean countries and South Africa. It differs significantly from evidence for European countries where automatic stabilizers played a more important role (Cantó et al. 2021). 
Figure 3: Decomposition of changes in mean disposable household income by quartile; Tanzania, Uganda, 2020

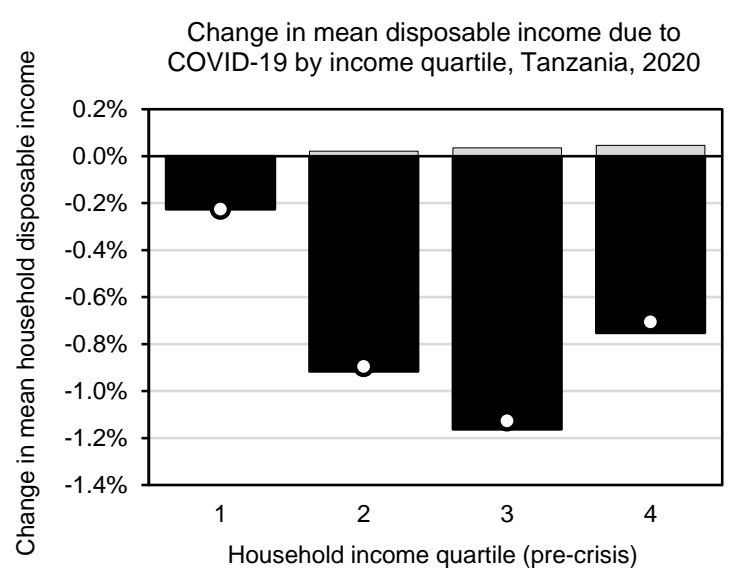

- Earnings

$\square$ Automatic stabilizers

- Disposable income

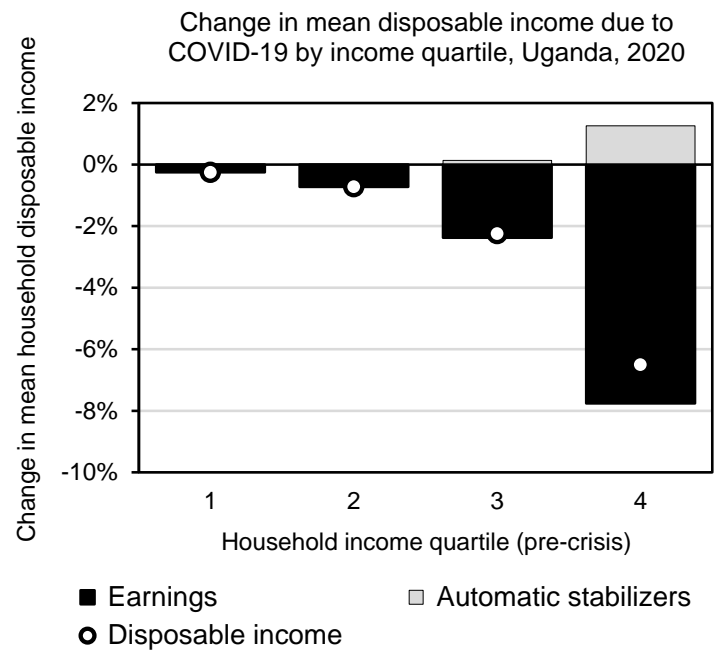

Change in mean disposable income due to automatic stabilization of tax-benefit policies by income quartile, Tanzania, 2020

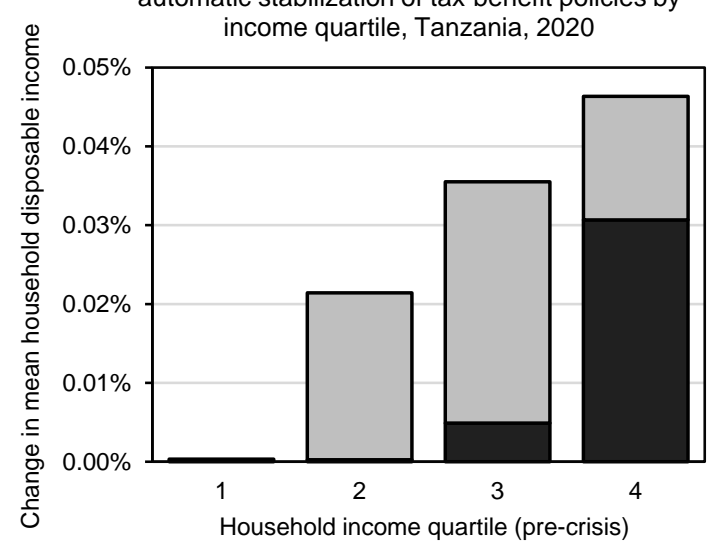

口Taxes $\quad$ QSocial Insurance Contributions

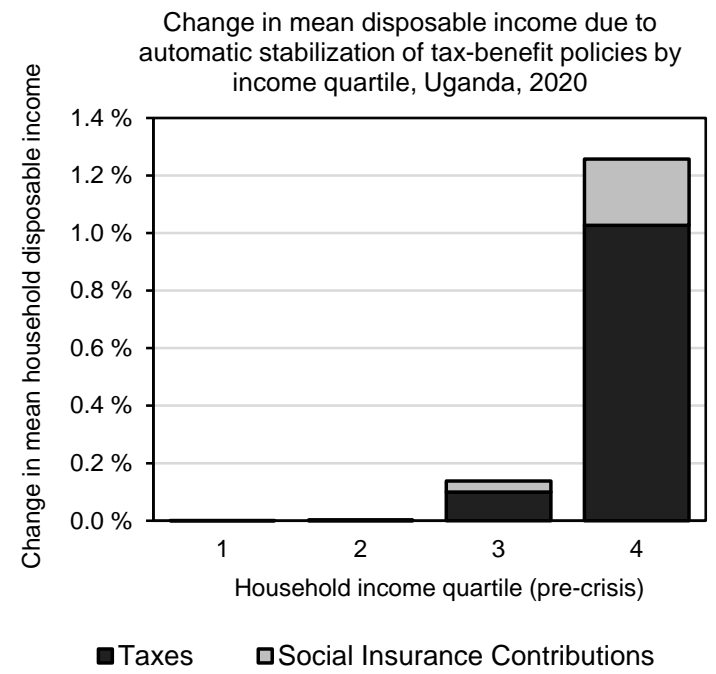

Note: the figures decompose the income shock from COVID-19 in 2020 into contributions from different sources. See Figure 2 above for details.

Source: authors' elaboration using TAZMOD, the tax-benefit microsimulation model for Tanzania, and the Tanzania Household Budget Survey (HBS, 2017-18), and UGAMOD, the tax-benefit microsimulation model for Uganda, and the Uganda National Household Survey (UNHS, 2016-17).

Our findings are driven by two structural differences between most developing countries and developed countries: First, the large share of the informal sector in the economy means that the personal income tax and social security system (black and light grey bars in right panels of Figures 3 and 4) cannot act and support people's income through lower contributions in times of crisis.

Second, social protection systems are of very limited scale in SSA with low coverage rates, low benefit amounts and benefits usually not means-tested based on market income (striped bar in right panels of Figures 2 and 3). Existing social protection programmes are in turn largely proxy means-tested or rely on categorical targeting and are therefore unable to react to income shocks by including new beneficiaries.

In addition, COVID-19-related discretionary tax-benefit policy measures made a difference most notably in Zambia but less so in Ghana and Mozambique. As discussed above no measures of significance were taken by Tanzania and Uganda. In Zambia, the Emergency Cash Transfer clearly 
cushioned the limited earnings shock that affected the bottom half of the distribution. In addition, the discontinuation of the school feeding programme-which is also characterised as a COVIDrelated discretionary policy change — has been offset by the positive impact of the Emergency Cash Transfer. This result needs to be considered as a lower bound estimate of the effect as we are unable to model the expansion of benefit coverage, as discussed above. In Mozambique, COVIDrelated policies nearly eliminated income losses of the second quartile while this is not the case for other income groups. ${ }^{24}$

Finally, the picture for Ghana is quite different from other countries. The large income reduction in the bottom quartile (over 16 percent) can be attributed mainly to the discontinuation of the inkind school feeding programme for pre-high school students in public schools which is treated as a COVID-related policy change. For poorer households, its negative impact is larger than the negative impact of the earnings shock in itself and offsets the positive impact of all other discretionary measures.

\subsection{Small cushioning impact of tax-benefit policies for poverty and inequality}

In this subsection, we show how the impact of COVID-19 on disposable incomes feeds through to poverty (using the internationally comparative US $\$ 1.9 /$ day threshold) and inequality based on the Gini coefficient (Table 4).

In general, the results point to relatively modest negative effects on absolute poverty rates as measured by FGT( 0$)$, ranging from $2.16 \mathrm{ppt}$ (3.0 per cent) in Zambia to $0.31 \mathrm{ppt}(0.5$ per cent) in Tanzania (columns $\mathrm{C}$ and $\mathrm{D}$ in Table 4). ${ }^{25}$ Bearing in mind significant methodological differences, these results are broadly in line with the literature on the impact of COVID-19 on poverty in SSA. ${ }^{26}$ Sumner et al. (2020) and Valensisi (2020) estimate a 2.5 and respectively 2.7 percentage points increase in poverty in SSA. Country-specific results by Sumner et al. for the scenario of a 5 per cent contraction of consumption per capita sit closest with our estimates that reflect only the first nine months of the crisis. Estimates by Barletta et al. (2021) for Mozambique are higher, with an increase between 4.3 and 9.9 percentage points in 2020 based on consumption and the national poverty line.

The US\$1.9 line may be considered a rather high cutoff point with nearly half (Ghana) and up to 82 per cent (Mozambique) of the population falling below in terms of disposable income before the pandemic. We therefore also estimate the change in the poverty gap, FGT(1), to analyse poverty dynamics below the poverty threshold and find a more pronounced negative impact with relative increases between 4.4 per cent (Ghana) and 0.8 per cent (Tanzania).

\footnotetext{
24 The small mitigating effect of benefits in the top quartile happens as some households would become eligible for the BSSP qualifying due to the means test at individual and household level given that even in the top quartile some households are not far off the poverty line.

${ }^{25}$ Younger et al. (2020) estimate an increase of the poverty rate by $7.9 \%$ for Uganda based on significantly larger, shocks as assumed by International Growth Centre and the Ministry of Finance to various incomes. The size of shocks assumed is considerably larger than what we estimate from sectoral GDP numbers and what the World Bank Phone Survey Data that have been published in the meantime reveal.

${ }^{26}$ Also see Table 1 in Sumner et al. (2020) for a comparison on the differences between the forecasting approaches used in these studies. The studies use micro data from PovCalNet estimating changes to poverty for select countries using GDP growth forecasts and are sensitive to a range of assumptions such as the pass-through rate of the GDP contraction to household income/consumption. The studies fully abstract from the workings of the tax-benefit system on incomes and ultimately welfare measures, the main interest of our study.
} 
In terms of inequality, the relative increase is most pronounced in Mozambique ( +1.7 per cent), the country with the highest Gini before the crisis. The impact is lowest for Uganda with a zero effect, and Ghana and Zambia both recording relative increases of +0.8 per cent.

Table 4: Impact of COVID-19 on poverty and inequality, and decomposition

\begin{tabular}{|c|c|c|c|c|c|c|c|}
\hline & & \multicolumn{3}{|c|}{ Welfare measure } & \multicolumn{3}{|c|}{ Change in welfare measure } \\
\hline & & \multirow[b]{2}{*}{$\begin{array}{c}\text { Pre- } \\
\text { crisis } \\
\text { scenario }\end{array}$} & \multirow[b]{2}{*}{$\begin{array}{c}\text { Crisis } \\
\text { scenario }\end{array}$} & \multirow[b]{2}{*}{$\begin{array}{c}\text { Total } \\
\text { change } \\
(\%)\end{array}$} & \multirow[b]{2}{*}{$\begin{array}{c}\text { Total } \\
\text { change } \\
\text { (abs.) }\end{array}$} & \multicolumn{2}{|c|}{$\begin{array}{l}\text { Decomposition of total } \\
\text { change (abs.) }\end{array}$} \\
\hline & & & & & & $\begin{array}{l}\text { Effect of } \\
\text { COVID } \\
\text { policies }\end{array}$ & $\begin{array}{c}\text { Other } \\
\text { effects } \\
\text { (earnings } \\
\text { shock and } \\
\text { automatic } \\
\text { stabilizers) }\end{array}$ \\
\hline & & $(\mathrm{A})$ & (B) & (C) & (D) & $(\mathrm{E})$ & $(\mathrm{F})$ \\
\hline \multirow{3}{*}{ Ghana } & $\begin{array}{l}\text { Poverty rate, } \\
\text { FGT(0) }\end{array}$ & 50.58 & 51.97 & $+2.7 \%$ & $+1.38^{\star \star \star}$ & +0.17 & $+1.22^{\star \star \star}$ \\
\hline & $\begin{array}{l}\text { Poverty gap, } \\
\text { FGT(1) }\end{array}$ & 35.05 & 36.60 & $+4.4 \%$ & $+1.55^{\star \star \star}$ & $+0.38^{\star \star \star}$ & $+1.17^{\star \star \star}$ \\
\hline & Gini coefficient & 78.97 & 79.61 & $+0.8 \%$ & $+0.65^{\star \star \star}$ & $+0.12^{\star \star \star}$ & $+0.52^{\star \star \star}$ \\
\hline \multirow{3}{*}{ Mozambique } & $\begin{array}{l}\text { Poverty rate, } \\
\text { FGT(0) }\end{array}$ & 82.03 & 83.63 & $+1.9 \%$ & $+1.60 * \star \star$ & $-0.02^{\star \star}$ & $+1.62^{\star \star \star}$ \\
\hline & $\begin{array}{l}\text { Poverty gap, } \\
\text { FGT(1) }\end{array}$ & 67.99 & 70.39 & $+3.5 \%$ & $+2.41^{\star \star \star}$ & $-0.11^{\star \star \star}$ & $+2.52^{\star \star \star}$ \\
\hline & Gini coefficient & 81.41 & 82.81 & $+1.7 \%$ & $+1.40^{\star \star \star}$ & $-0.10 * \star \star$ & 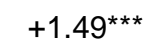 \\
\hline \multirow{3}{*}{ Zambia } & $\begin{array}{l}\text { Poverty rate, } \\
\text { FGT(0) }\end{array}$ & 71.53 & 73.69 & $+3.0 \%$ & $+2.16^{\star \star \star}$ & $-0.26^{\star \star \star}$ & $+2.42^{\star \star \star}$ \\
\hline & $\begin{array}{l}\text { Poverty gap, } \\
\text { FGT(1) }\end{array}$ & 53.77 & 55.90 & $+4.0 \%$ & $+2.13^{\star \star \star}$ & $-0.53^{\star \star \star}$ & $+2.66^{\star \star \star}$ \\
\hline & Gini coefficient & 73.16 & 73.73 & $+0.8 \%$ & $+0.57^{\star \star \star}$ & $-0.33^{\star \star \star}$ & 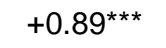 \\
\hline \multirow{3}{*}{ Tanzania } & $\begin{array}{l}\text { Poverty rate, } \\
\text { FGT(0) }\end{array}$ & 59.34 & 59.65 & $+0.5 \%$ & $+0.31^{\star \star \star}$ & - & $+0.31^{\star \star \star}$ \\
\hline & $\begin{array}{l}\text { Poverty gap, } \\
\text { FGT(1) }\end{array}$ & 42.23 & 42.59 & $+0.8 \%$ & $+0.35^{\star \star \star}$ & - & $+0.35^{\star \star \star}$ \\
\hline & Gini coefficient & 65.65 & 65.84 & $+0.3 \%$ & 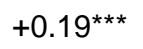 & - & 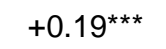 \\
\hline \multirow{3}{*}{ Uganda } & $\begin{array}{l}\text { Poverty rate, } \\
\text { FGT(0) }\end{array}$ & 71.40 & 72.80 & $+2.0 \%$ & $+1.40^{\star \star * *}$ & - & $+1.40^{\star \star \star}$ \\
\hline & $\begin{array}{l}\text { Poverty gap, } \\
\text { FGT(1) }\end{array}$ & 48.66 & 49.91 & $+2.6 \%$ & $+1.25^{\star \star *}$ & - & $+1.25^{\star \star \star}$ \\
\hline & Gini coefficient & 66.52 & 66.54 & $+0.0 \%$ & +0.02 & - & +0.02 \\
\hline
\end{tabular}

Note: the table presents estimates of the impact of the COVID-19 pandemic on measures of poverty and inequality in the respective countries in 2020. Columns (A) and (B) show the poverty rate, poverty gap and Gini coefficient in the scenarios without and with shocks from COVID-19. The crisis scenario also accounts for COVID-related tax-benefit policy changes made in 2020, when modelled. Outcomes are derived based on harmonized equivalence scales and a standard international poverty line (disposable income under US\$1.9 per day). Column (C) and (D) show the overall impact of the crisis in percentages (B/A-1) and as an absolute change $(B-A)$, respectively. Column $(E)$ shows the independent effect of the discretionary policy changes made during the crisis. Column (F) shows other effects, namely the automatic stabilization of the tax-benefit system and the COVID-induced earnings shock. Statistical significance shown for the absolute changes $(D, E, F)$ is based on bootstrapped standard errors after 200 replications. Significance levels indicated as ${ }^{*} p<0.1,{ }^{\star \star} p<0.05,{ }^{\star \star \star} p<$ 0.01 .

Source: authors' elaboration using SOUTHMOD tax-benefit microsimulation models and relevant survey data for the respective countries.

COVID-19-related policies played a limited role (columns $\mathrm{E}$ and $\mathrm{F}$ of Table 4) in mitigating the adverse effects of the crisis on poverty and inequality in 2020. In a counterfactual scenario with no policies adopted in response to COVID-19, headcount poverty would have increased by 2.42 ppt in Zambia (instead of $2.16 \mathrm{ppt}$ when accounting for these policies) and $1.62 \mathrm{ppt}$ in Mozambique (instead of $1.60 \mathrm{ppt}$ ). In Ghana, the discontinuation of the school feeding 
programme overrides the beneficial impact of all other COVID-related policies, and therefore poverty would have increased less in the absence of the combined COVID-related policies, by $1.22 \mathrm{ppt}$ (instead of $1.38 \mathrm{ppt}$ without the policy changes).

In terms of the poverty gap and inequality, the discretionary policy measures had a relatively larger impact in Zambia, reflecting the additional benefits going to the poorest households through the Emergency Cash Transfer. A similar observation can be made for Mozambique, where the measures did cushion some of the increase in the poverty gap and inequality, unlike for the poverty headcount. Yet, their contribution is nevertheless very limited.

\subsection{Sensitivity analysis}

As discussed above we explored an alternative method to impute income losses at the individual level using micro data from World Bank Phone Surveys (WBPS) for Uganda in a separate technical note (Oliveira et al. 2021). Due to lack of similar data for the other countries analysed ${ }^{27}$ here, results presented above are based on moving workers within sectors randomly into unemployment and thus reducing their earnings to zero. By contrast, the WBPS data allows for a more sophisticated approach, where industry-level GDP shocks are identical to the random allocation method but transitions to unemployment are modelled based on individuals' characteristics. This transition approach accounts for the fact that certain types of workers within sectors had a higher probability of losing their income. This approach is similar to recent studies, including those for developing countries, such as Avenalleda et al. (2021), Cantó et al. (2021), Barnes et al. (2021), Christl et al. (2021), and Jara et al. (2021).

While in principle it is superior to the random allocation method, the reliability of results using the transition method relies to a great extent on the quality of and the details provided in the micro data. Unfortunately, the WBPS data for Uganda offers considerably less detail and thus only allows for limited modelling of transitions as compared to the data applied in other studies. More specifically, the data only indicates income losses at the household level and does not provide information on the size of the income loss at the individual level, posing challenges to selecting individuals for transitions and for predicting their income changes. Also, the WBPS offers less detailed industry classification than the UNHS that underlies UGAMOD. This generates differences in how the GDP shock is distributed that go beyond the differences generated by the methods themselves.

As shown in Figure 4 changes in income-group specific mean disposable incomes due to earnings losses are more pronounced throughout the income distribution when modelling labor market transitions using the WBPS (right panel) compared to the random allocation method (left panel). The additional loss in disposable income is generated mainly by greater earnings losses among those in the informal sector, and in particular informal farmers, reflecting a greater vulnerability of the informal sector to the COVID-19 shock.

Given the relatively greater shock to earnings in the informal sector, the income stabilization coefficient is reduced from 17.0 per cent to 16.4 per cent while the contribution of automatic stabilizers is similar (see Appendix E for full tables). The increase in headcount poverty is slightly more pronounced when using the transition approach (+1.51 ppt vs. $+1.40 \mathrm{ppt})$. The increase in the poverty gap is in turn slightly lower and Gini decreases by -0.60 ppt or 0.9 per cent (vs. no change).

${ }^{27}$ At the time of writing similar surveys were ongoing for all countries analysed but full micro data had not been released. 
Figure 4: Change in mean disposable income only due to earnings losses from COVID-19 by income quartile and employment type using the random allocation method (left) and transition method (right) for Uganda
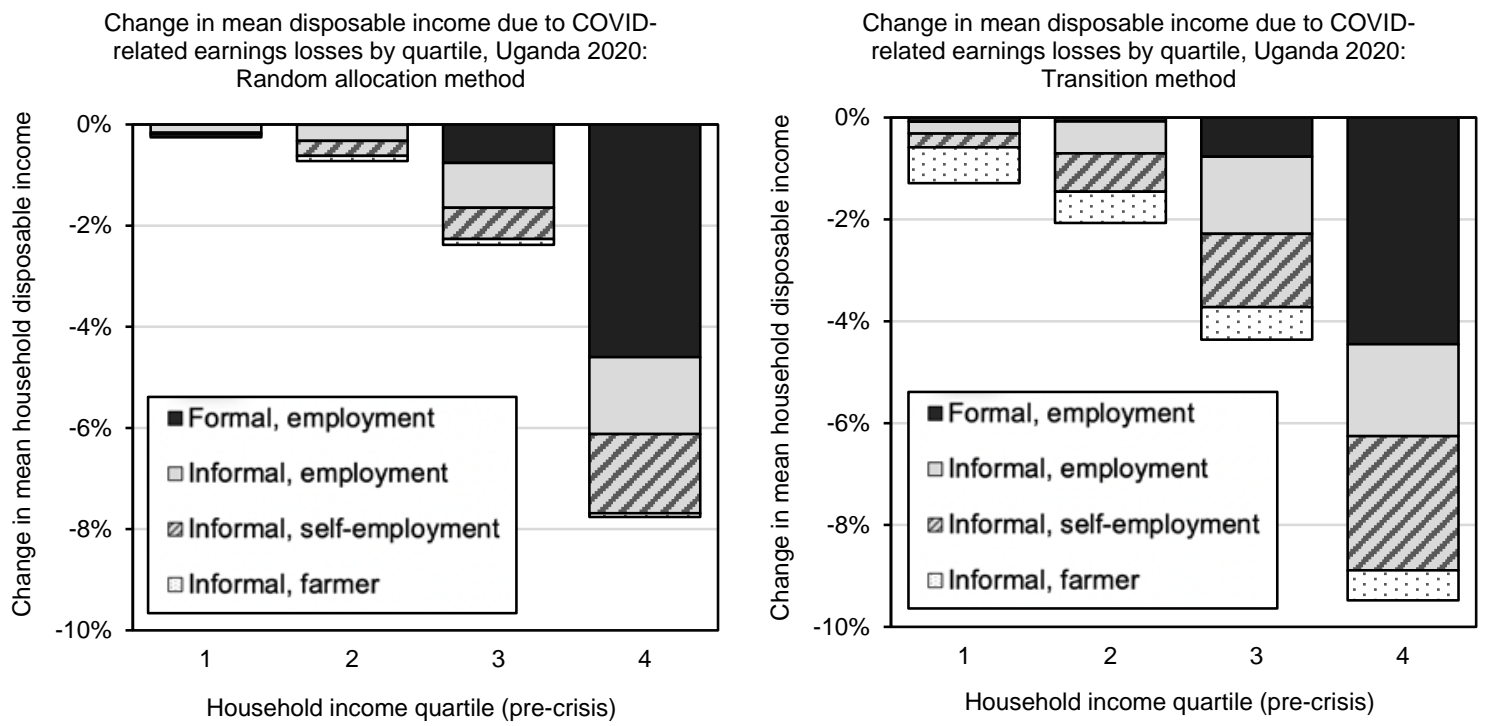

Note: the figures show decomposition outcomes derived using the random allocation method (left) and the transition method (right). The figures decompose earnings losses resulting from COVID-19 across different employment types. In both figures, effects are shown separately for different income quartiles, derived from disposable household incomes in the pre-crisis scenario. All changes in earnings are based on per capita earnings at the household level.

Source: authors' elaboration using UGAMOD, the tax-benefit microsimulation model for Uganda, as well as data from the Uganda National Household Survey (UNHS, 2016-17) and the World Bank High-Frequency Phone Surveys in Uganda (2020).

\section{Conclusions}

The COVID-19 global pandemic presents a virtually unprecedented challenge to many developing countries, and in particular for sub-Saharan Africa. With their minimal social protection schemes and weak healthcare systems, SSA countries are particularly vulnerable to the virus. Given the severely constrained fiscal space faced by most African governments, implementing appropriate policy responses is challenging. Devising effective public responses not only to address the immediate health crisis, but also to limit the economic hardships resulting from COVID-19, for example in the form of emergency income support measures and tax waivers is critical.

Focusing on five countries in Africa (Ghana, Mozambique, Tanzania, Uganda, Zambia), our analysis offers insights into both the economic impact of the crisis and the effectiveness of COVID-19-related policies in alleviating the adverse effects of the crisis on disposable incomes and ultimately poverty and inequality. Our main contribution consists in mapping out at the micro level how earnings shocks carry over to disposable incomes, poverty and inequality, and the role tax-benefit policies played in buffering the COVID-19 shock across the income distribution. We provide nuanced impact estimates, including a detailed decomposition of the impact of automatic stabilizers that pre-existed the crisis and discretionary measures taken in response to the crisis.

We find modest increases in income inequality and poverty. Across all countries, automatic stabilizers have a very limited effect in mitigating income losses. New COVID-19-related policy measures also played a very small role, with the exception of Zambia's Emergency Cash Transfer that clearly limited losses in disposable income at the bottom of the income distribution. And while Ghana implemented several COVID-19-related policies, their mitigating effects were countered 
by the pausing of its large school feeding program, which led to a similar decrease in disposable incomes at the bottom of the income distribution as the earnings shock in itself.

Our findings highlight several structural factors that will remain important as the pandemic continues. First, agriculture served as a buffer against income losses for poorer households, mitigating earnings losses to a certain extent. While this is good news initially, it also means people's livelihoods are more reliant on stable climate conditions. Also, moving out of poverty via the services sector had definitely become more difficult or even impossible in 2020, and might remain so, also depending on lockdown measures in 2021 and beyond. Second, in environments characterized by high informality and benefit systems without monetary means-testing elements, automatic stabilizers are by definition not able to provide much immediate relief. Unless governments manage to considerably increase the formal sector, (more) discretionary policy making will also be key in future crises, despite its clear drawbacks such as much slower response to crises. Third, the nascent social protection floors that existed before the pandemic were not sufficiently comprehensive to support vulnerable households through the crisis. We have abstracted here from the discussion on how (additional) social protection measures could be sustainably financed in the medium to long-run given countries' severely constrained fiscal space; see Furceri et al. (2021) on how fiscal policies and long-run inequality outcomes related in past crises). Finally, our analysis focuses on 2020 which in hindsight has to be considered the early days of the pandemic, with comparatively lower caseloads and reported deaths across African countries.

\section{References}

Addison, T., K. Sen, and F. Tarp (2020). 'COVID-19: Macroeconomic Dimensions in the Developing World'. WIDER Working Paper 74/2020. Helsinki: UNU-WIDER. https://doi.org/10.35188/UNU-WIDER/2020/831-3

Adu-Ababio, K., R. Darko Osei, J. Pirttilä, and P. Rattenhuber (2021). SOUTHMOD Country Report Ghana - GHAMOD v2.3 (forthcoming). Helsinki: UNU-WIDER.

Alesina, A., and F. Giavazzi (2013) (eds). Fiscal Policy after the Financial Crisis. Chicago: University of Chicago Press for National Bureau of Economic Research. https://doi.org/10.7208/chicago/9780226018584.001.0001

Auerbach, A., and D. Feenberg (2000). The Significance of Federal Taxes as Automatic Stabilizers. Journal of Economic Perspectives, 14(3): 37-56. https://doi.org/10.1257/jep.14.3.37

Ayhan Kose, M., and N. Sugawara (2021). 'Understanding the depth of the 2020 global recession in 5 charts'. World Bank Blogs. Available at: https://blogs.worldbank.org/opendata/understandingdepth-2020-global-recession-5-charts (accessed 1 August 2021).

Avellaneda, A., R. Chang, D. Collado, H.X. Jara, A. Mideros, L. Montesdeoca, D. Rodriguez, J. Torres, and $\mathrm{O}$. Vanegas (2021). Assessing the cushioning effect of tax-benefit policies in the Andean region during the COVID-19 pandemic. CeMPA Working Paper Series, No. 8/21. Available at: https://www.microsimulation.ac.uk/publications/publication-536923/ (accessed September 2021).

Bargain, O., X. Jara, P. Kwenda, and M. Benhura (2021). 'Income Distribution and the Potential of Redistributive Systems in Africa: A Decomposition Approach'. Journal of African Economies, (forthcoming).

Bargain, O. and T. Callan (2010). 'Analysing the Effects of Tax-benefit Reforms on Income Distribution: A Decomposition Approach'. Journal of Economic Inequality, 8(1): 1-21. https://doi.org/10.1007/s10888-008-9101-4

Barletta, G., F. Castigo, E.-M. Egger, M. Keller, V. Salvucci and F. Tarp (2021). ‘The Impact Of Covid-19 On Consumption Poverty In Mozambique’. WIDER Working Paper 94/2021. Helsinki: UNUWIDER. https://doi.org/10.35188/UNU-WIDER/2021/034-4 
Barnes, H., G. Espi-Sanchis, M. Leibbrandt, M. Leolo, D. McLennan, M. Noble, J. Pirttilä, W. Steyn, B. van Vrede, and G. Wright (2021). 'Analysis of the distributional effects of Covid-19 and state-led remedial measures in South Africa'. SA-TIED Working Paper 170. Available at: https://satied.wider.unu.edu/sites/default/files/SA-TIED-WP-170.pdf (accessed September 2021).

Blundell, R., M. Costa Dias, R. Joyce, and X. Xu (2020). 'COVID-19 and Inequalities'. Fiscal Studies, 41(2): 291-319. https://doi.org/10.1111/1475-5890.12232

Bourguignon, F., and Spadaro, M. (2006). 'Microsimulation as a tool for evaluating redistribution policies'. Journal of Economic Inequality Volume, 4(77-106). https://doi.org/https://doi.org/10.1007/s10888-005-9012-6

Brewer, M., and Tasseva, I. (2021). 'Did the UK Policy Response to Covid-19 Protect Household Incomes?'. The Journal of Economic Inequality. https://doi.org/10.1007/s10888-021-09491-w

Cantó, O., C. Figari, C. Fiorio, S. Kuypers, S. Marchal, and M. Romaguera de la Cruz, et al. (2021). "Welfare resilience at the onset of the COVID-19 pandemic in a selection of European countries: Impact on public finance and household incomes. Review of Income and Wealth. https://doi.org/10.1111/roiw.12530

Castelo, V., Castigo, F., Cardoso, J., Noble, M., and Wright, G. (2020). SOUTHMOD Country Report Mozambique - MOZMOD v2.6. Helsinki: UNU-WIDER. Available at: https://www.wider.unu.edu/sites/default/files/Publications/Report/PDF/SOUTHMODMozambique-v2-6.pdf (accessed September 2021).

Christl, M., S. De Poli, T. Hufkens, A. Peichl and M. Ricci (2021). 'The Role of Short-Time Work and Discretionary Policy Measures in Mitigating the Effects of the Covid-19 Crisis in Germany'. CESifo Working Paper 9072. Munich: CESifo.

Club of Mozambique (2021) 'Cereal crops in Mozambique exceeded 1.9 million tons in 2020 - survey'. Available at https:/ / clubofmozambique.com/news/cereal-crops-in-mozambique-exceeded-1-9million-tons-in-2020-survey-193834/ (accessed on 19 September 2021).

Council of Foreign Affairs (2021). Tanzania's COVID Denialism Harms its Economic Future. 23 February 2021. Available at https://www.cfr.org/blog/tanzanias-covid-denialism-harms-itseconomic-future (accessed on 27 August 2021).

Decoster, A., Pirttilä, J., Sutherland, H. and Wright, G. (2019). 'SOUTHMOD: Modelling Tax-benefit Systems in Developing Countries'. International Journal of Microsimulation 12(1): 1-12. https://doi.org/10.34196/ijm.00192

Devarajan, S., D. Go, M. Maliszewska, I. Osorio-Rodarte, and H. Timmer (2013). 'Stress-Testing Africa's Recent Growth and Poverty Performance'. Policy Research Working Paper 6517. Washington, DC: World Bank. https://doi.org/10.1596/1813-9450-6517

Dolls, M., Fuest, C. and Peichl, A. (2012). 'Automatic Stabilizers and Economic Crisis: US vs. Europe', Journal of Public Economics 96(3-4): 279-294. https://doi.org/10.1016/j.jpubeco.2011.11.001

Dolls, M., C. Fuest, A. Peichl and C. Wittneben (2020). 'Fiscal Consolidation and Automatic Stabilization: New Results'. EconPol Working Paper 39. A publication of EconPol Europe, the European Network of Economic and Fiscal Policy Research. Munich: ifo Institute.

FAO (2020). 'Social Protection: Effective and Inclusive Response and Recovery in the Context of COVID-19 in Africa'. Accra, Ghana. https://doi.org/10.4060/ca8988en

Figari, F., and C. Fiorio (2020). 'Welfare Resilience in the Immediate Aftermath of the COVID-19 Outbreak in Italy'. EUROMOD Working Paper EM6/20. Colchester: Institute for Social and Economic Research, University of Essex.

Furceri, D., P. Loungani, J. Ostry, and P. Pizzuto (2021). 'Will COVID-19 Have Long-Lasting Effects on Inequality? Evidence from Past Pandemics'. IMF Working Paper 2021/127. Washington, DC: International Monetary Fund. https://doi.org/10.5089/9781513582375.001

Gasior, K., H. Barnes, M. Jouste, J. Lastunen, D. McLennan, M. Noble, P., Oliveira, R., Rattenhuber, and G. Wright (2021). 'Full-Year Adjustment for Modelling COVID-19 Policies in SOUTHMOD Tax- 
Benefit Microsimulation Models'. WIDER Technical Note 18/2021. Helsinki: UNU-WIDER. https://doi.org/10.35188/UNU-WIDER/WTN/2021-18

Gasior, K., C. Leventi, M. Noble, G. Wright, and H. Barnes (2021). The distributional impact of tax and benefit systems in five African countries. International Journal of Sociology and Social Policy, (ahead of print). https:// doi.org/10.1108/IJSSP-01-2021-0008

Gentilini, U., M. Almenfi, I. Orton, and P. Dale (2020). Social Protection and Jobs Responses to COVID19: A Real-Time Review of Country Measures. 11 December 2020 and 14 May 2021 Update. World Bank, Washington, DC. World Bank. Available at https://openknowledge.worldbank.org/handle/10986/33635 (accessed 29 August 2021).

Hale, T., N. Angrist, R. Goldszmidt, B. Kira, A. Petherick, T. Phillips, S. Webster, E. Cameron-Blake, L. Hallas, S. Majumdar, and E. Tatlow (2021). 'A global panel database of pandemic policies (Oxford COVID-19 Government Response Tracker).' Nature Human Behaviour. https://doi.org/10.1038/s41562-021-01079-8

ILO (2020). 'ILO Monitor: Covid-19 and the World of Wor. Second edition'. Briefing Note. Available at: https://www.ilo.org/wcmsp5/groups/public/---dgreports/--dcomm/documents/briefingnote/wcms_740877.pdf (accessed 1 October 2020).

Jara, H.X., L. Montesdeoca, and I. Tasseva (2021). 'The Role of Automatic Stabilizers and Emergency Tax-benefit Policies During the COVID-19 Pandemic in Ecuador'. WIDER Working Paper 4/2021. Helsinki: UNU-WIDER. https://doi.org/10.35188/UNU-WIDER/2021/938-9

KGM and Associates Pty Ltd (2019). The Eora Global Supply Chain Database, 2nd edition. https://worldmrio.com/countrywise/ (accessed 01.09.2020].

Kniesner, T., and J. Ziliak (2002). 'Tax Reform and Automatic Stabilization'. American Economic Review, 92(3): 411-433. https://doi.org/10.1257/00028280260136264

Kyyrä, T., J. Pirttilä, and T. Ravaska (2021). 'The Corona Crisis and Household Income: The Case of a Generous Welfare State'. VATT Mimeo 61. Helsinki: VATT Institute for Economic Research. https://urn.fi/URN:ISBN:978-952-274-271-1

Lastunen, J. (2021). 'Deriving shocks to household consumption expenditures from the associated income shocks resulting from COVID-19'. WIDER Technical Note 16/2021. Helsinki: UNUWIDER. https://doi.org/10.35188/UNU-WIDER/WTN/2021-16

Leventi, C., and F. Picos (2019). The tax structure of an economy in crisis: Greece 20092017. EUROMOD.

Leyaro, V., E. Kisanga, M. Noble, G. Wright, and H. Barnes (2021). SOUTHMOD Country Report Tanzania - TAZMOD v2.1. Helsinki: UNU-WIDER. Available at: https://www.wider.unu.edu/sites/default/files/Publications/Report/PDF/SOUTHMODTanzania-v2-1.pdf (accessed September 2021).

Lustig, N., V. Martinez Pabon, F. Sanz, and S. Younger. (2020). 'The Impact of COVID-19 Lockdowns and Expanded Social Assistance on Inequality, Poverty and Mobility in Argentina, Brazil, Colombia and Mexico'. CGD Working Paper 2020/556. Washington, DC: Center for Global Development. Available at: https://www.cgdev.org/sites/default/ files/impact-covid-19-lockdowns-and-expandedsocial-assistance.pdf (accessed September 2021).

McKay, A., and R. Reis (2016). The Role of Automatic Stabilizers in the U.S. Business Cycle. Econometrica'. 84(1): 141-94. https://doi.org/10.3982/ecta11574

McLennan, D. (2021). 'Iterative Proportional Fitting for Re-weighting Input Data in SOUTHMOD Microsimulation Models'. WIDER Technical Note 17/2021. Helsinki: UNU-WIDER. https://doi.org/10.35188/UNU-WIDER/WTN/2021-17

Nakamba-Kabaso, P., S. Nalishebo, F. Muleya, M. Kalikeka, C. Byaruhanga, and J. Jele et al. (2020). SOUTHMOD Country Report Zambia - MicroZAMOD v2.4. Helsinki: UNU-WIDER. Available at: https://www.wider.unu.edu/sites/default/ files/Publications/Report/PDF/SOUTHMODZambia-v2-4-2020_0.pdf (accessed September 2021). 
Ohnsorge, F., and S. Yu (2021). The Long Shadow of Informality. Washington, DC: World Bank. https://doi.org/10.1596/35782

Oliveira, R., J. Lastunen, E. Nichelatti, and P. Rattenhuber (2021). Imputation methods for adjusting SOUTHMOD input data to income losses due to the COVID-19 crisis. WIDER Technical Note 19/2021. Helsinki: UNU-WIDER. https://doi.org/10.35188/UNU-WIDER/WTN/2021-19

Paulus, A., and I. Tasseva (2020). 'Europe through the Crisis: Discretionary Policy Changes and Automatic Stabilizers'. Oxford Bulletin of Economics and Statistics. https:// doi.org/10.1111/obes12354

Reporters Without Borders (2020). 'Tanzanian Media Unable to Cover Covid-19 Epidemic'. News, November 5. Reporters Without Borders. Available at: https://rsf.org/en/news/tanzanian-mediaunable-cover-covid-19-epidemic (accessed 27 August 2021)

Ritchie H., E. Mathieu, L. Rodés-Guirao, C. Appel, C. Giattino, E. Ortiz-Ospina, J. Hasell, B. Macdonald, D. Beltekian,and M. Roser (2020) 'Coronavirus Pandemic (COVID-19)'. Published online at OurWorldInData.org. Available at: https:// ourworldindata.org/coronavirus (accessed 27 August 2021).

Sumner, A., E. Ortiz-Juarez, and C. Hoy (2020). 'Precarity and the Pandemic: Covid-19 and Poverty Incidence, Intensity, and Severity in Developing Countries'. WIDER Working Paper 77/2020. Helsinki: UNU-WIDER. https:/ / doi.org/10.35188/UNU-WIDER/2020/834-4

Te Velde, D.W. (2020). 'Economic Impacts of and Policy Responses to the Coronavirus Pandemic: Early Evidence from Africa'. https://set.odi.org/wp-content/uploads/2020/03/Economic-impacts-ofand-policy-responses-to-the-coronavirus-pandemic-early-evidence-from-Africa.pdf (accessed 1 December 2020).

Waiswa, R., J. Okello Ayo, M. Noble, C. Byaruhanga, S. Kavuma, and G. Wright (2020). SOUTHMOD Country Report Uganda: UGAMOD v1.4. Helsinki: UNU-WIDER. Available at: https://www.wider.unu.edu/sites/default/files/Publications/Report/PDF/SOUTHMOD-Ugandav1-4.pdf (accessed September 2021).

Valensisi, G. (2020). 'COVID-19 and Global Poverty: Are LDCs Being Left Behind?' WIDER Working Paper 73/2020. Helsinki: UNU-WIDER. https:// doi.org/10.35188/UNU-WIDER/2020/830-6

World Bank. (2021a). 'GDP growth (annual \%) - Tanzania, Mozambique, Zambia, Ghana, Uganda'. World Bank. Available at: https:// data.worldbank.org/indicator/NY.GDP.MKTP.KD.ZG?end=2019\&locations=TZ-MZZM-GH-UG\&start=2000 (accessed 26 August 2021).

World Bank. (2021b). 'Poverty headcount ratio at $\$ 1.90$ a day (2011 PPP) (\% of population) - Tanzania, Mozambique, Zambia, Ghana, Uganda'. World Bank. Available at: https:/ / data.worldbank.org/indicator/SI.POV.DDAY?end=2017\&locations=TZ-MZ-ZM-GHUG\&start=2009 (accessed 26 August 2021).

World Bank. (2021c). 'High-Frequency Phone Survey on COVID-19 2020-2021'. World Bank. Available at: https:// microdata.worldbank.org/index.php/catalog/3765 (accessed 1 May 2021).

World Bank. (2021d). 'Impact of COVID-19 crisis on agriculture. Evidence from five sub-Saharan African countries'. World Bank. Available at: https://documents.worldbank.org/en/publication/documentsreports/documentdetail/304561611294945287/impact-of-covid-19-crisis-on-agriculture-evidencefrom-five-sub-saharan-african-countries (accessed 2 September 2021).

Wright, G., M. Noble, H. Barnes, A. Moechtar, D. McLennan, A.A. Yusuf, K. Gasior and R. Muyanto (2021). 'Estimating the Distributional Impacts of the COVID-19 Pandemic and Remedian Tax and Benefit Policies on Poverty in Indonesia'. CeMPA Working Paper 02/21.

UNU-WIDER (2021a). 'Word Income Inequality Database (WIID)'. Version 31 March 2021. Helsinki: UNU-WIDER. https://doi.org/10.35188/UNU-WIDER/WIID-310521

UNU-WIDER (2021b). 'Government Revenue Dataset (GRD)'. Version 2021. Helsinki: UNU-WIDER. https://doi.org/10.35188/UNU-WIDER/GRD-2021 
UNU-WIDER (2021c). 'SOUTHMOD Modelling Conventions' (forthcoming). Helsinki: UNU-WIDER.

Younger, S., A. Musisi, W. Asiimwe, N. Ntungire, J. Rauschendorfer, and P. Manwaring (2020).

'Estimating Income Losses and Consequences of the Covid-19 Crisis in Uganda'. CEQ Working

Paper 110. New Orleans: CEQ Institute, Tulane University. 


\section{Appendix A: COVID-19 cases and deaths across countries analysed}

Figures A1 and A2 show the daily new confirmed cases and confirmed deaths per million people, respectively. Note that Tanzania has not reported these figures.

Figure A1: Daily new confirmed cases per million people

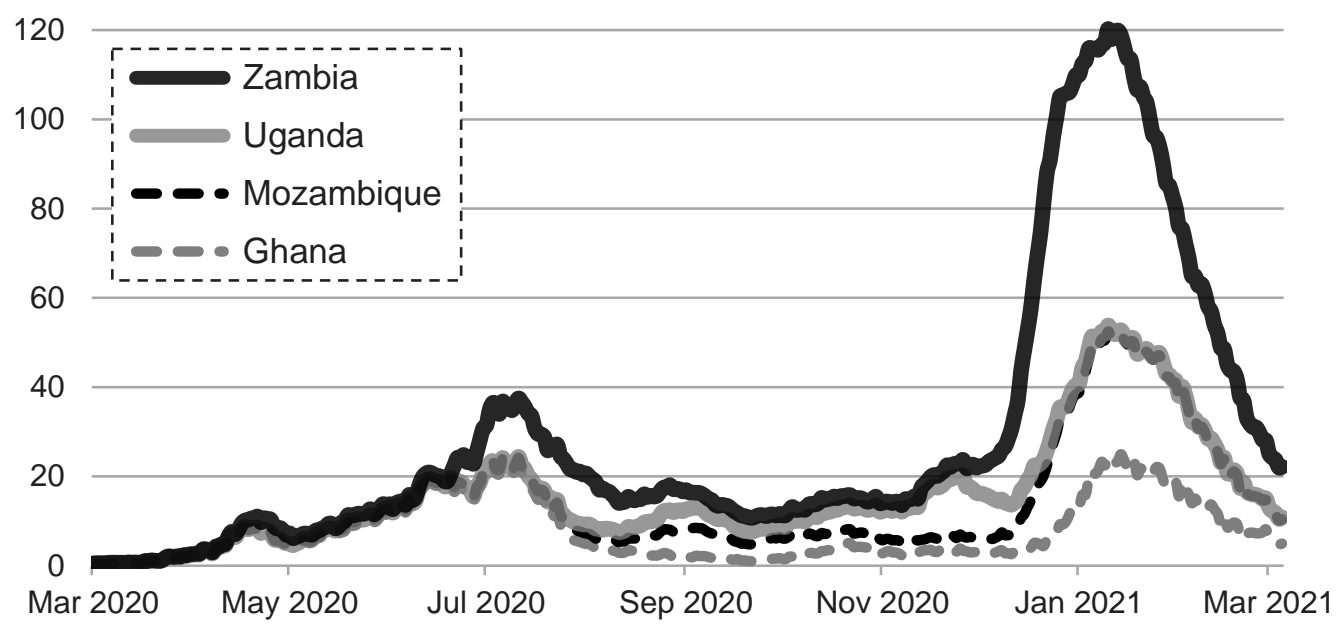

Source: authors' illustration based on data from Ritchie et al. (2020).

Figure A2: Daily new confirmed deaths per million people

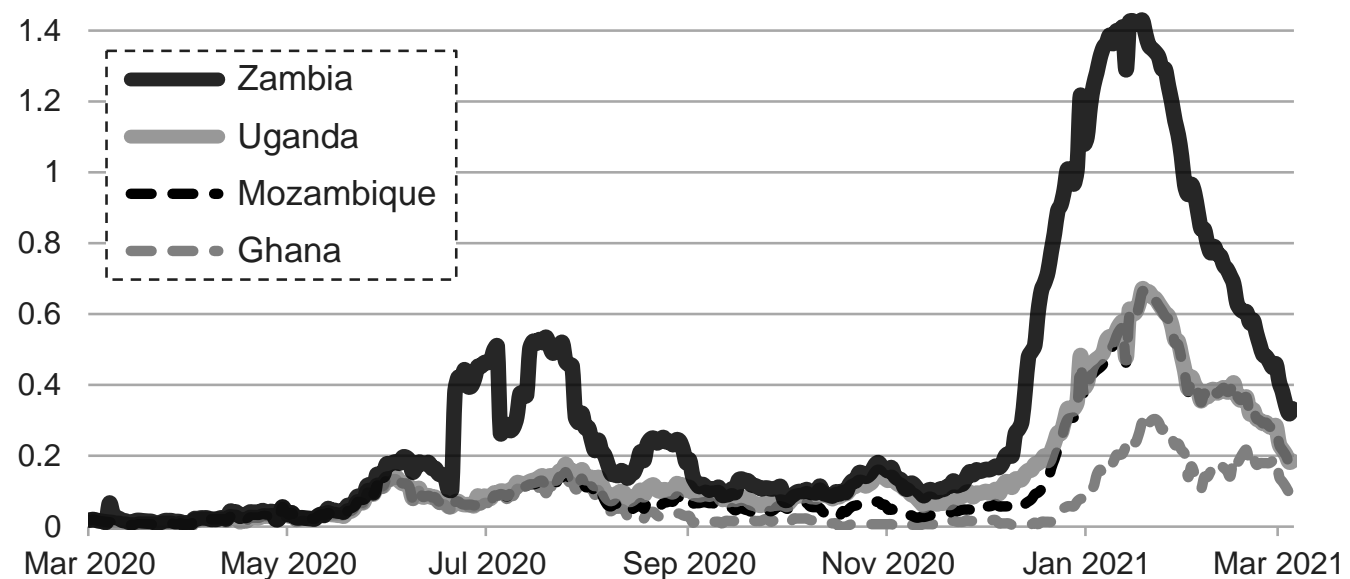

Source: authors' illustration based on data from Ritchie et al. (2020). 
Appendix B: Lockdown measures across countries according to the Oxford Stringency Index 2020

Figure B1 illustrates changes in the Oxford Government Stringency Index in 2020 for the countries studied.

Figure B1: Oxford Government Stringency Index for Ghana, Mozambique, Tanzania, Uganda and Zambia in 2020

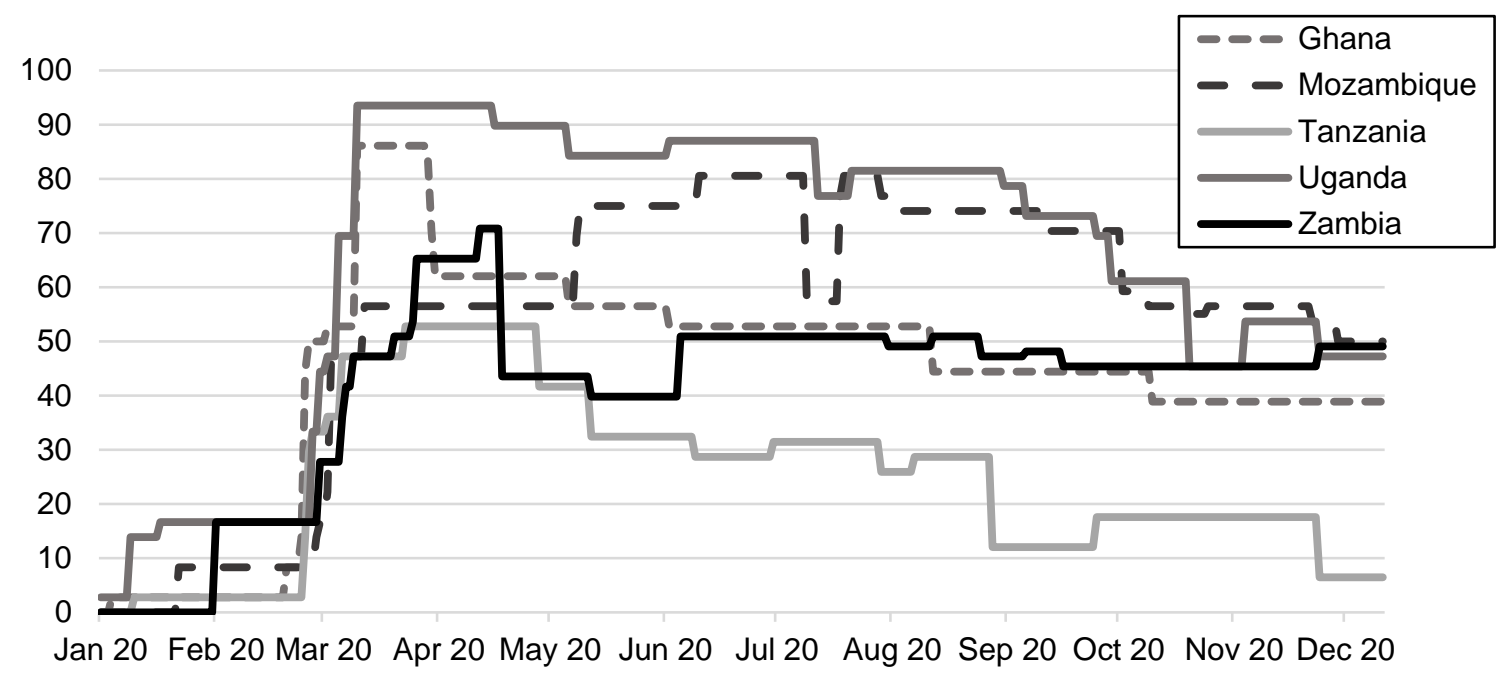

Source: authors' illustration based on data from Hale et al. (2021). 


\section{Appendix C: Estimated GDP shocks at the industry level}

We derive shocks to national and industry-level GDP by estimating the deviation of 2020 GDP from its counterfactual value, which is derived based on pre-COVID growth trends. First, we use annual or quarterly industry-level GDP data from each country under consideration, and annualize the figures where necessary. Second, we compute the economic shock in 2020 as the deviation of 2020 GDP for each industry from a counterfactual value derived based on the pre-COVID, 201719 linear trend, accounting for inflation. See Table 1 in the main text for the relevant data sources and the technical note by Oliveira et al. (2021) for more information.

Figure C1: Industry-level GDP shocks in 2020, Ghana

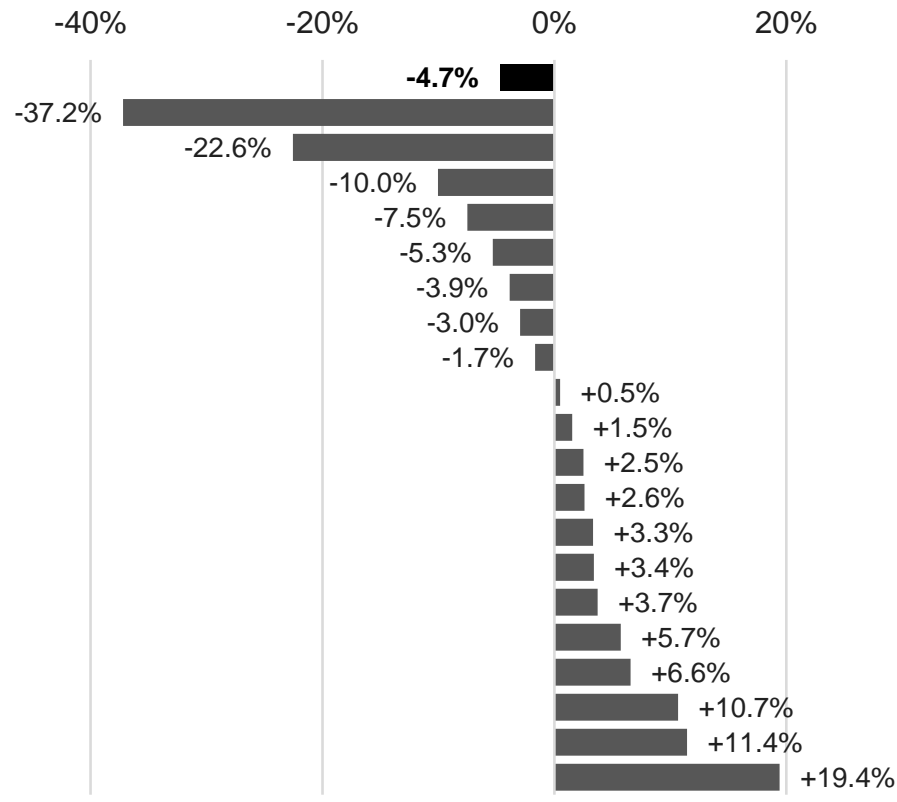

All Sectors
Hotels \& Restaurants
Mining \& Quarrying
Forestry \& Logging
Professional \& Administrative Services
Health \& Social Work
Trade; Repair of Vehicles
Manufacturing
Other Service Activities
Livestock
Transport \& Storage
Education
Electricity
Public Administration
Crops
Construction
Information \& Communication
Water \& Sewerage
Real Estate
Financial \& Insurance Activities
Fishing

Source: authors' elaboration based on national GDP data (GDP at constant 2013 prices by economic activity, Ghana Statistical Service, May 2021).

Figure C2: Industry-level GDP shocks in 2020, Mozambique

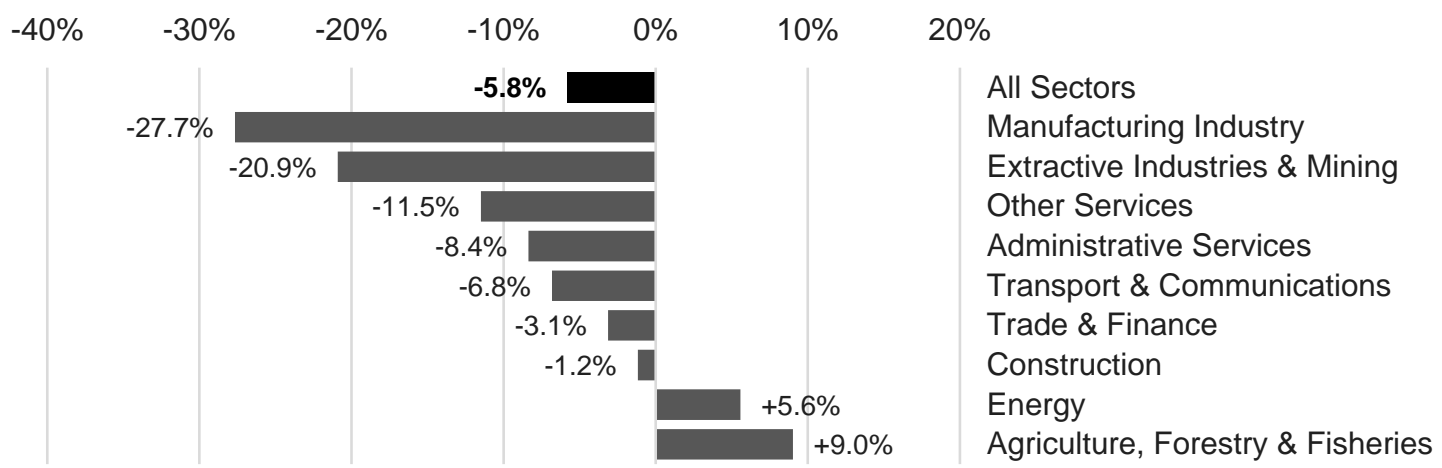

Source: authors' elaboration based on national GDP data (quarterly GDP at constant 2014 prices by industry, National Institute of Statistics, Mozambique, Publication of National Accounts IV for Q4/2020, February 2021). 


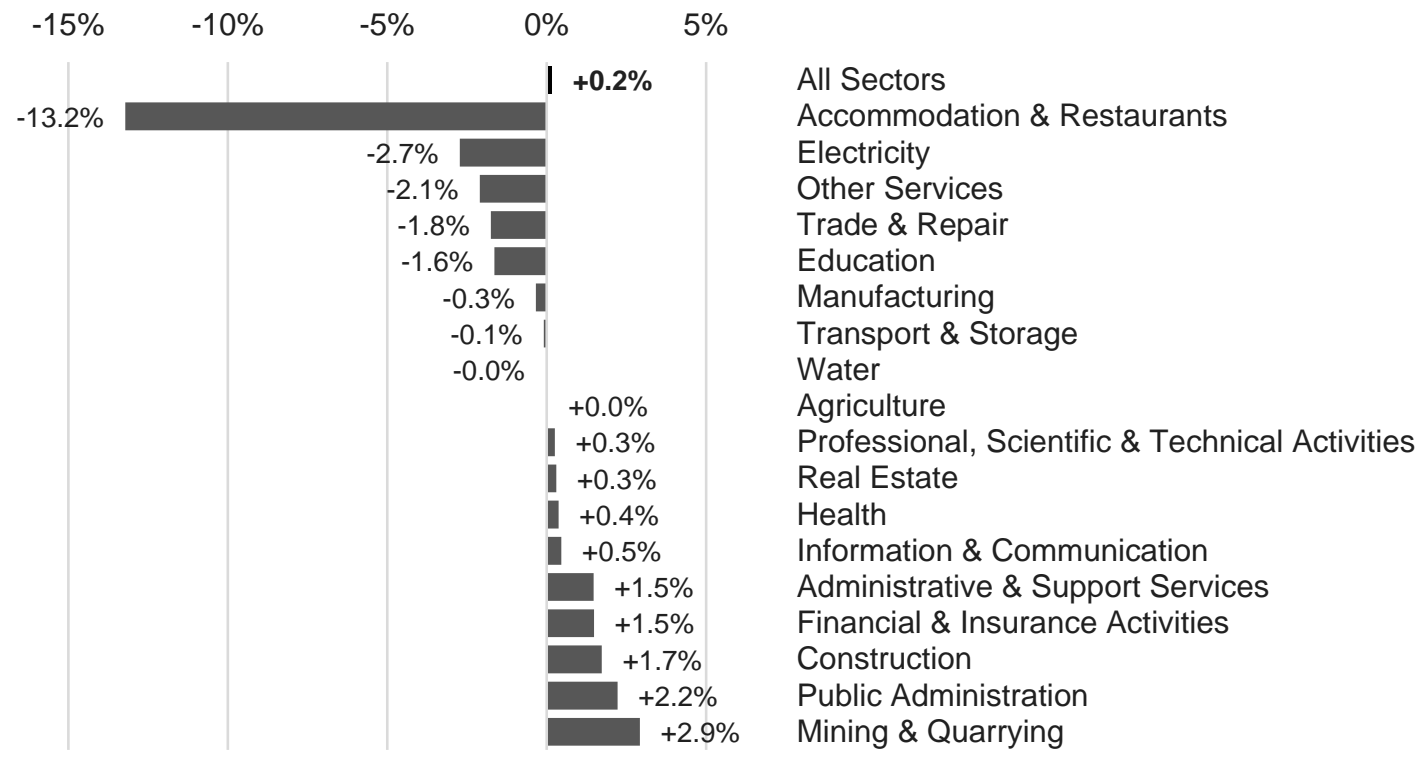

Source: authors' elaboration based on national GDP data (GDP at 2015 prices by economic activity; 2020 Q4 predicted based on 2017-19 Q4 GDPs; Tanzania National Bureau of Statistics, December 2020).

Figure C4: Industry-level GDP shocks in 2020, Zambia

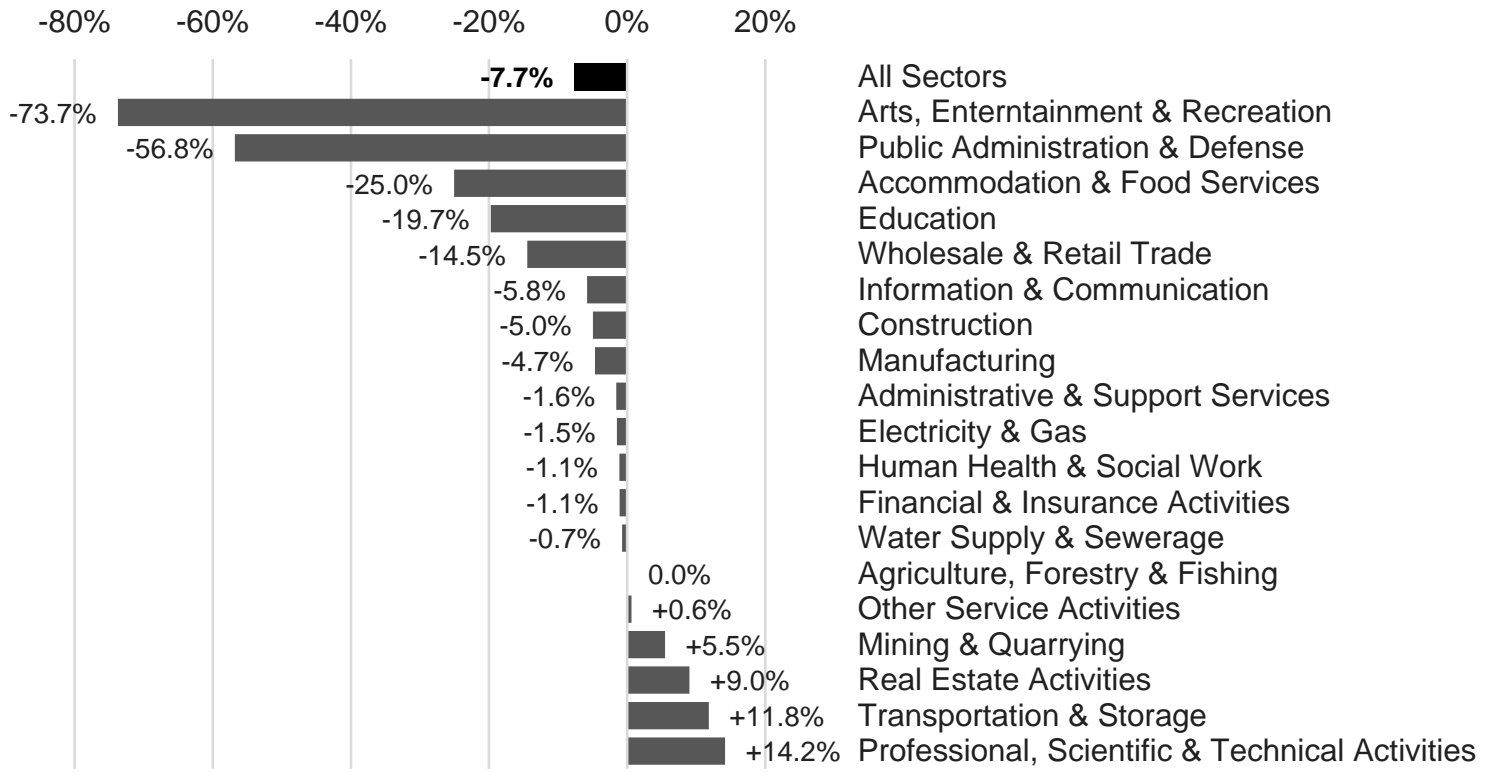

Source: authors' elaboration based on national GDP data (quarterly gross value added by industry at constant 2010 prices, Zambia Statistics Agency, Monthly Bulletins up to vol. 217 April 2021). 
Figure C5: Industry-level GDP shocks in 2020, Uganda (industry classification as in UNHS, used for random allocation method)

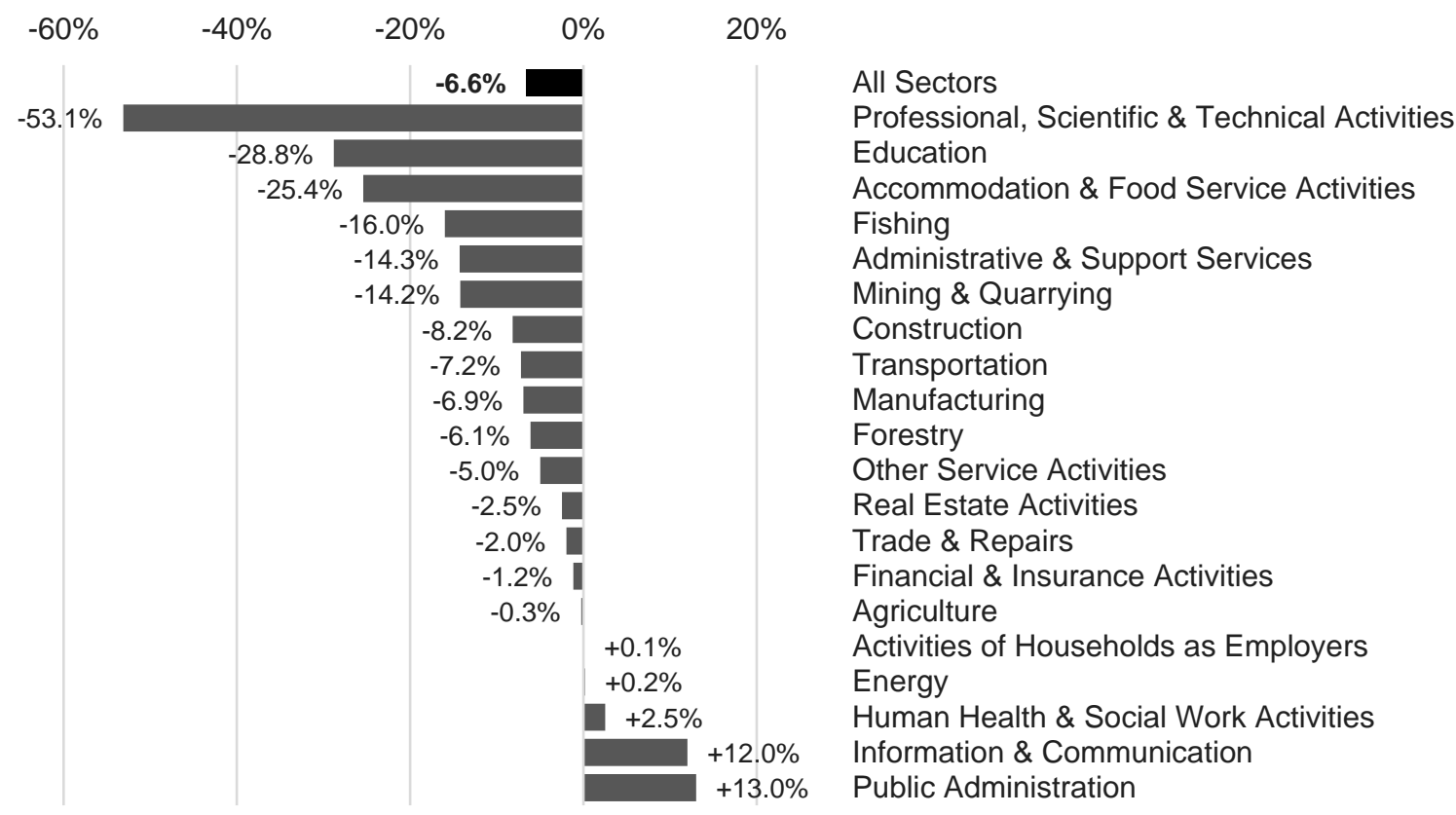

Source: authors' elaboration based on national GDP data (quarterly GDP at constant 2016/17 prices up to Q4/2020, Uganda Bureau of Statistics, National Accounts, March 2021).

Figure C6: Industry-level GDP shocks in 2020, Uganda (industry classification as in WBPS, aggregating sectors found in UNHS, used for transition method)

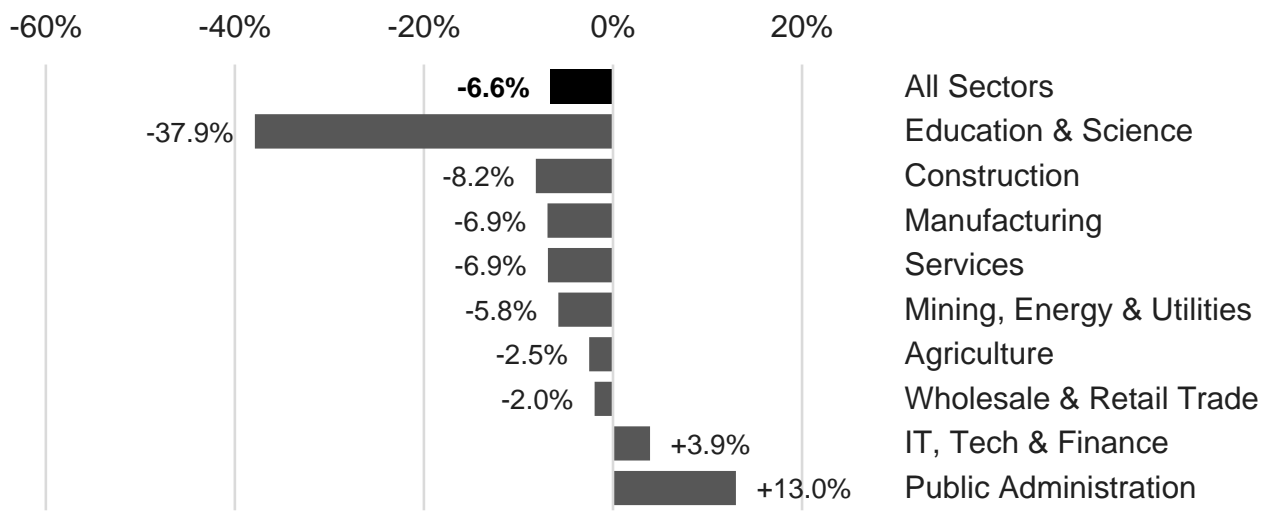

Source: authors' elaboration based on national GDP data (quarterly GDP at constant 2016/17 prices up to Q4/2020, Uganda Bureau of Statistics, National Accounts, March 2021). 


\section{Appendix D: Implementation of COVID-19-related tax-benefit policy measures and implementation in simulations}

Table D1: Tax-benefit policy measures in Ghana

\begin{tabular}{|c|c|c|c|c|}
\hline $\begin{array}{l}\text { Name of policy } \\
\text { measure }\end{array}$ & Description & $\begin{array}{l}\text { Policy modelled: } \\
\text { Y for yes, } \\
\text { N for no, } \\
\text { P for partially }\end{array}$ & $\begin{array}{l}\text { Duration of } \\
\text { measures }\end{array}$ & Source \\
\hline $\begin{array}{l}\text { Personal income tax } \\
\text { waivers for frontline and } \\
\text { medical personnel }\end{array}$ & $\begin{array}{l}\text { Individuals whose employer is providing } \\
\text { frontline and medical services are } \\
\text { exempted from paying personal income } \\
\text { tax. Policy is implemented through } \\
\text { employers via the pay-as-you-earn } \\
\text { (PAYE) system. }\end{array}$ & $\mathrm{Y}$ & $\begin{array}{l}\text { From } 1 \text { May } \\
2020 \text { to } \\
\text { December }\end{array}$ & $\begin{array}{l}\text { Presidency of the Republic of Ghana, Update N.05: Measures } \\
\text { Taken to Combat the Spread of the Coronavirus }\end{array}$ \\
\hline $\begin{array}{l}\text { Waiver/reduction of utility } \\
\text { tariffs }\end{array}$ & $\begin{array}{l}\text { Water costs waived for three months; } \\
\text { electricity costs waived fully for the } \\
\text { poorest of the poor, } 50 \% \text { waived for all } \\
\text { other consumers. }\end{array}$ & $\begin{array}{l}\text { Y, calculating costs } \\
\text { saved on expenditure } \\
\text { for water and } \\
\text { electricity, but } \\
\text { disregarding lifeline } \\
\text { consumers of } \\
\text { electricity. }\end{array}$ & $\begin{array}{l}\text { From } 9 \text { April } \\
2020 \text { for } 3 \\
\text { months }\end{array}$ & $\begin{array}{l}\text { Address to the nation by President Akufo-Addo on updates to } \\
\text { Ghana's enhanced response to COVID-19, } 9 \text { April } 2020\end{array}$ \\
\hline $\begin{array}{l}\text { School feeding for final } \\
\text { year junior and senior } \\
\text { high school students }\end{array}$ & $\begin{array}{l}\text { Provision of meals to final-year junior } \\
\text { and senior high school students to } \\
\text { enable them to complete their final } \\
\text { exams during the pandemic. }\end{array}$ & $\begin{array}{l}\text { Y, using monetized } \\
\text { value of in-kind } \\
\text { benefit. }\end{array}$ & $\begin{array}{l}\text { From } 24 \text { August } \\
2020 \text { to } 18 \\
\text { September } 2020\end{array}$ & $\begin{array}{l}\text { Presidency of the Republic of Ghana, Update N.15: Measures } \\
\text { Taken to Combat the Spread of the Coronavirus }\end{array}$ \\
\hline $\begin{array}{l}\text { School feeding for } \\
\text { second year senior high } \\
\text { school and junior high } \\
\text { school students }\end{array}$ & $\begin{array}{l}\text { Provision of meals to continuing junior } \\
\text { and senior high school students until the } \\
\text { end of the academic year in December. }\end{array}$ & $\begin{array}{l}\text { Y, using monetized } \\
\text { value of in-kind } \\
\text { benefit. }\end{array}$ & $\begin{array}{l}\text { From } 5 \text { October } \\
2020 \text { to } 14 \\
\text { December } 2020\end{array}$ & $\begin{array}{l}\text { Presidency of the Republic of Ghana, Update N.15: Measures } \\
\text { Taken to Combat the Spread of the Coronavirus }\end{array}$ \\
\hline $\begin{array}{l}\text { Discontinuation of the } \\
\text { school feeding } \\
\text { component of the school } \\
\text { capitation grant }\end{array}$ & $\begin{array}{l}\text { In-kind benefit not handed out to } \\
\text { students due to closure of schools } \\
\text { during lockdown. }\end{array}$ & $\begin{array}{l}\text { Y, using monetized } \\
\text { value of in-kind } \\
\text { benefit. }\end{array}$ & $\begin{array}{l}\text { From } 30 \text { March } \\
2020 \text { to } 31 \\
\text { December } 2020\end{array}$ & $\begin{array}{l}\text { This applies automatically as schools benefiting from this } \\
\text { grant are closed due to the pandemic. }\end{array}$ \\
\hline
\end{tabular}


Additional food rations supplied to existing

LEAP beneficiaries

Food rations are supplied specifically to

benefit from LEAP transfers. areas and essential

workers

Distribution of food in lockdown areas and provision of medical supplies to essential workers.

\section{Support to lockdown}

$\mathrm{Y}$, using monetized value of in-kind

benefit, assuming

LEAP beneficiaries perfectly targeted to poorest households.

$\mathrm{N}$

From 9 April

2020 for 3

Address to the nation by President Akufo-Addo on updates to

months to

lockdown areas

and essential

workers

\section{Business support to} formal and informal

micro, small and

medium-sized

enterprises (MSMEs-

CAP BuSS)

\section{COVID-19 Alleviation}

and Revitalization of

Enterprises Support

(CARES) - Stabilization

\section{Component}

Reliefs by the Ghana

Revenue Authority SMSEs and start-ups mainly funded by

\section{$\mathrm{N}$, information on} eligibility not

sufficient.

From 1-30 June

Mastercard Foundation Recovery and Resilience Program for

period ended in MSMEs to provide support to businesses in Ghana affected

June)

by COVID-19

\section{$\mathrm{N}$, currently not}

is available for

to December

2020

$\mathrm{N}$, data on do not provide sufficient information to mode the measures.
From 30 March 2020 to 31

tatement to Parliament on the economic impact of the COVID-19 pandemic on the economy of Ghana
(NBSS)

\section{From July 20202020 Mid-year budget statement}

\section{Emergency programme supporting}

the Mastercard Foundation and the

National Board for Small Scale

Industries (NBSSI). This part of the greater CAP initiative.

Firm support, building/including existing initiatives. This is not limited to MSMEs.

All firms who are facing challenges due the greater CAP initiative.

1. Extension of due dates for filling of taxes from 4 months to 6 months after the end of the basis year.

2. Grant a remission of penalties on principal debts to Tax payers who redeem, their outstanding debts due GRA up to 30th June 2020.

3. Waive VAT on donations of stock of equipment and goods for fighting the Covid-19 Pandemic.

4. Waive taxes on selected Third-Tier Pension withdrawals.

5. Permit the deduction of contributions and donations towards COVID-19 as allowable expense for tax purposes. 


\begin{tabular}{|c|c|c|c|c|}
\hline New Tax Policies & $\begin{array}{l}\text { 1. COVID-19 Health Recovery Levy Act } \\
\text { 2021, Act } 1068 \text { : special } 1 \% \text { levy } \\
\text { imposed on 'Vat-able' goods and } \\
\text { services to support implementation of } \\
\text { COVID-19 response policiesr; } \\
\text { 2. Penalty and Interest Waiver Act } 2021 \text {, } \\
\text { Act 1065: waiver on penalties and } \\
\text { interest payments on accumulated tax } \\
\text { arrears up to December } 2020 \text {. } \\
\text { Applicable to agents able to file tax } \\
\text { returns and arrange for payment of } \\
\text { outstanding by end of December } 2021 \text {; } \\
\text { 3. Income Tax (Amendment) Act } 2021 \text {, } \\
\text { Act } 1066: 30 \% \text { rebate for payment of } \\
\text { quarterly tax instalment for selected } \\
\text { sectors and suspension of payment for } \\
\text { specific self-employed persons and } \\
\text { owners of commercial vehicles; } \\
4 \text {. Energy Sector Levies (Amendment) } \\
\text { Act } 2021 \text {, Act } 1064 \text { : imposition of • Ghp } \\
20 \text { per litre on petrol and diesel and GHp } \\
18 \text { per kg of LPG for payment of energy } \\
\text { sector bills. An additional Ghp } 10 \text { per } \\
\text { litre on petrol and diesel to serve as } \\
\text { sanitation and pollution levy; } \\
5 \text {. Financial Sector Recovery Levy Act } \\
2021 \text { (Act } 1067 \text { ): banks to pay } 5 \% \text { of } \\
\text { profit before tax as levy. }\end{array}$ & $\begin{array}{l}\mathrm{N} \text {, data on do not } \\
\text { provide sufficient } \\
\text { information to model } \\
\text { the measures. }\end{array}$ & $\begin{array}{l}\text { 1. 1st May } 2021 \\
\text { to December } \\
2021 ; \\
\text { 2. 1st April } 2021 \\
\text { to December } \\
2021 ; \\
\text { 3. Applicable } \\
\text { from second } \\
\text { quarter of } 2021 \\
\text { to fourth quarter } \\
\text { of } 2021 ; \\
\text { 4. May to } \\
\text { December } 2021 \text {; } \\
\text { 5. end of June to } \\
\text { end of December } \\
\text { 2021 }\end{array}$ & $\begin{array}{l}\text { https://gra.gov.gh/news/portfolio/implementation-of-new-tax- } \\
\text { policies-in-the-2021-budget-statement-and-economic-policy/ }\end{array}$ \\
\hline
\end{tabular}


Table D2: Tax-benefit policy measures in Mozambique

\begin{tabular}{|c|c|c|c|c|}
\hline Name of policy measures & Description & $\begin{array}{l}\text { Policy modelled: } \\
\text { Y for yes, } \\
\text { N for no, } \\
\text { P for partially }\end{array}$ & $\begin{array}{l}\text { Duration of } \\
\text { measures }\end{array}$ & Source \\
\hline $\begin{array}{l}\text { Suspension of negotiations } \\
\text { for minimum wage } \\
\text { adjustments across sectors }\end{array}$ & $\begin{array}{l}\text { Minimum wage adjustments were } \\
\text { suspended for all industries for } 2020 \text {. }\end{array}$ & $\mathrm{Y}$ & $\begin{array}{l}\text { From } 13 \text { April } \\
2020 \text { until } 31 \\
\text { December } 2020\end{array}$ & MITSS Comissao Consultiva do Trabalho \\
\hline Additional BSSP payments & $\begin{array}{l}\text { Three additional payments equal to the } \\
\text { monthly transfers the household already } \\
\text { received in the BSSP programme }\end{array}$ & $\mathrm{Y}$ & $\begin{array}{l}\text { From August to } \\
\text { December } 2020\end{array}$ & $\begin{array}{l}\text { ILO Mozambique, available at https://www.social- } \\
\text { protection.org/gimi/RessourcePDF.action?id=57176 }\end{array}$ \\
\hline $\begin{array}{l}\text { VAT exemption for sugar, } \\
\text { cooking oil and soap }\end{array}$ & $\begin{array}{l}\text { VAT exemption was provided for sugar, } \\
\text { cooking oil and soap products. These } \\
\text { products had already been exempted from } \\
\text { VAT for the past five years up until } 31 \\
\text { December } 2019 \text {. Due to COVID-19, the } \\
\text { exemption was set up again at the end of } \\
\text { May. }\end{array}$ & $\mathrm{Y}$ & $\begin{array}{l}\text { From June } 2020 \\
\text { until } 31 \\
\text { December } 2020\end{array}$ & BR I serie n¹12 Lei 5/2020 de 29 de Maio \\
\hline $\begin{array}{l}\text { A subsidy of } 30 \% \text { of } \\
\text { salaries for civil servants in } \\
\text { Health and Defense Sector }\end{array}$ & $\begin{array}{l}\text { This policy sets up a 'risk subsidy' of } 30 \% \\
\text { for health personnel of the national health } \\
\text { service and related institutions. The } \\
\text { subsidy is intended for personnel that work } \\
\text { in exceptional conditions or in situations of } \\
\text { high endemic or epidemic incidence, and } \\
\text { for those that may be exposed to } \\
\text { radioactive and toxic substances. The } \\
\text { purpose is to minimize the physical and } \\
\text { psychological stress caused by constant } \\
\text { exposure to biological risks, which leads to } \\
\text { the development of infectious diseases } \\
\text { such as HIV, pulmonary tuberculosis, } \\
\text { hepatitis, musculoskeletal disorders and } \\
\text { cancerous diseases. }\end{array}$ & $\mathrm{N}$ & NA & Decreto $46 / 2020$ de 24 de Junho \\
\hline $\begin{array}{l}\text { Reduction of utility tariffs for } \\
\text { lifeline consumers }\end{array}$ & $\begin{array}{l}\text { The reduction of utility tariffs is } 50 \% \text { for } \\
\text { those in the social tariff group and } 10 \% \text { for } \\
\text { those in other groups, with the exception of } \\
\text { customers in the domestic category whose }\end{array}$ & $\begin{array}{l}\mathrm{P} \text {, the model simulates a } \\
50 \% \text { reduction in tariff for } \\
\text { households (all treated as } \\
\text { being on the 'social tariff') }\end{array}$ & $\begin{array}{l}\text { From } 1 \text { June } \\
2020 \text { until } 31 \\
\text { December } 2020\end{array}$ & $\begin{array}{l}\text { Clientes da Electricidade de Moçambique, E.P. } \\
\text { (EDM), 'Durante seis meses: EDM reduz tarifa de } \\
\text { energia para mitigar efeitos da COVID-19' } \\
\text { (https://www.edm.co.mz/pt/website- }\end{array}$ \\
\hline
\end{tabular}


tariff remains unchanged. Tariffs for the industrial sector are deferred for the period (this covers the fixed rate payments on electricity by companies in the industrial commercial, agricultural, services,

hospitality, catering, education and sports and cultural facilities, which are included in

the general tariff; and large 'low- and

medium-voltage' consumers with installed power up to $200 \mathrm{kVA}$, whose turnover registered a reduction above $30 \%$ due to

the pandemic. The cost of this measure is estimated at around 15 million dollars.

Total exemption from
customs duties and
miscellaneous taxes on the
import of medicines and
reagents, as well as all
COVID 19 prevention
material and ventilators

material and ventilators

Programa do Subsídio

Social Básico (PSSB) An exemption of fees for
drinking water up to $5 \mathrm{~m} 3$ The COVID-19 prevention material and ventilators are those included in a list previously approved by the Tax Authority until December 2020. for the period June to end

125kw/hr@1.07Mt per kw.

The deferred payments

for the industrial sector

are not simulated.
Dec 2020 using 0-
mobile/article/not\%C3\%ADcia/durante-seis-mesesedm-reduz-tarifa-de-energia-para-mitigar-efeitos)
Beneficiaries received a larger payment for $Y$ 2020). In the augmented payment month

the beneficiary received $3 x$ a normal

monthly payment i.e. 14 payments in the calendar year of 2020 instead of 12 .

Water supply to customers' facilities are no interrupted during the state of emergency, and the collection of water bills is

suspended from customers who consume

up to $5 \mathrm{~m} 3$. The respective bill can be paid after for which the state of emergency lasts

without fines. The collection of water bills is

stopped for all fixed and/or mobile public

fountains. just one month (some point in July/Aug/Sep

(n)

From May 2020 until December

2020

Decreto 23/2020 de 27 de Abril (Facilidades Aduaneiras e Fiscais para Mitigar os Efeitos Económicos do COVID-19)
For one month

between July-

September 2020
, the underpinning

dataset does not allow determinining whether

households obtain water

from a public or private supplier.
From 17 April 2020 until the state of

emergency is

terminated

\section{Circular n03/FIPAG/DG/900/2020}

No requirement to work for An obligation to work was removed fo $\mathrm{N}$

NA

Programa Accao Social health reasons due to the pandemic.

Produtiva payments 
Programa de Apoio Social PASD is no longer simulated in MOZMOD Directo (PASD) and Post as the programme is being phased out.

$\mathrm{N}$, payments only started

at the very end of 2020 .

NA

Emergency - Direct Social

$\mathrm{PE})$

Direct post-emergency transfers (PASD-PE

'Covid') were also introduced to support

BSSP Since most of the beneficiaries

received the benefit only in 2021 , and due

to lack of up-to-date data about this

programme, we do not simulate it for 2020 .
ILO Mozambique, available at: https://www.social-

protection.org/gimi/RessourcePDF.action?id=57176 
Table D3: Tax-benefit policy measures in Tanzania

Name of policy measures Description

Policy modelled: Duration of Source

$Y$ for yes,

measures

Source

$\mathrm{N}$ for no,

$P$ for partially

Charity support from institutions to

the special committee chaired by

the Prime-Minister

Informal support to hospitals and

Includes in-kind support; e.g for sanitizers, handwash facilities,

and masks.

orphanage centers

Conditionalities waived for PSSN II Conditionality was waived for the August and October 2020 bi-

cash transfers

monthly payments.

N

$\mathrm{N}$, as full

compliance with

conditionality is

assumed in base

model
Expansion of social security schemes
Government announced an expansion of social security scheme by US $\$ 32.1$ million to meet the increase in withdrawals benefits

for new unemployed due to COVID-19. information

available on who

benefitted.
Customs duty: $100 \%$ allowable deduction for contributions made to the AIDS Trust Fund as well as contributions made to the

Government for fighting against the pandemic

\section{Customs duty: Changes in}

Common External Tariff (CET) and amendments to the EAC Customs Management Act (EAC-CMA), 2004.

Applied only for those institutions that contributed to the ATF and $N$

to the government. This measure intends to encourage contributions to support the fight against these diseases.

Involves duty remission on raw materials used by domestic

manufacturers of items directly used in prevention, treatment and

management of COVID-19 pandemic. The grant duty remission

is on raw materials used by domestic manufacturers of items

used specifically for diagnosis, prevention, treatment and

management of the COVID- 19 pandemic at the duty rate of $0 \%$

for one year. The proposed changes are aimed at stimulating the

economy to safeguard livelihoods, jobs, businesses and

industrial recovery.

Duty remission on raw materials

Exempted items included under the fifth schedule of the EAC-

Customs Management Act, 2004 are supplies for diagnosis,

used by domestic mant

(t)

Covid19 Pandemic in

Tanzania March-May

2020 by the National

Bureau of Statistics

NA

NA

August and October Gentilini et al. (2021)

2020

From 1 July 2020
From 1 July 2020

Effective until the

Government

the pandemic.

From 1 July 2020 until the start of the financial year $2020 / 2021$
Gentilini et al. (2021)

Finance minister budget speech for FY 2020/21. Also see Deloitte

Budge Highlight 2020/21

Finance minister budget speech for FY 2020/21. Also see Deloitte Report on Tanzanian Budge Highlight 2020/21 
items directly used in prevention, treatment and management of

COVID-19 pandemic

prevention, treatment, and management of epidemics,

pandemics and health hazards as recommended by the

competent authority in the health ministry.

Increases in excise duty rates for non-petroleum products

Due to the impact of COVID-19, government minister has

proposed not to amend the specific duty rates upwards for all non-petroleum products on the back of suppressed inflation and the government's desire to incentivize industrial development and increase its contribution to the GDP. The measures involve all business units and manufacturing that are engaged in nonpetroleum products. financial year

2020/2021

Report on Tanzanian

Budget Highlight

2020/21

rom 17 April 2020

until the state of

emergency is

erminated

Finance minister budget

speech for FY 2020/21.

Also see Deloitte

Report on Tanzanian

Budget Highlight

2020/21 
Table D4: Tax-benefit policy measures in Uganda

\begin{tabular}{|c|c|c|c|c|}
\hline Name of policy measure & Description & $\begin{array}{l}\text { Policy modelled: } \\
\text { Y for yes, } \\
\text { N for no, } \\
\text { P for partially }\end{array}$ & $\begin{array}{l}\text { Duration of } \\
\text { measures }\end{array}$ & Source \\
\hline \multirow[t]{4}{*}{ Deferment of payment tax liability } & $\begin{array}{l}\text { Income taxpayers who were liable to pay tax on or after 1st April } 2020 \\
\text { and before } 30 \text { th June } 2020 \text {. }\end{array}$ & \multirow[t]{4}{*}{$\mathrm{N}$} & \multirow[t]{4}{*}{$\begin{array}{l}\text { 31st Dec } 2020 \text { until } \\
?\end{array}$} & \multirow{4}{*}{$\begin{array}{l}\text { Director, Tax and } \\
\text { Regulatory Services, } \\
\text { KPMG Uganda }\end{array}$} \\
\hline & $\begin{array}{l}\text { - For taxpayers in the business of education, tourism, manufacturing, } \\
\text { horticulture or floriculture. }\end{array}$ & & & \\
\hline & $\begin{array}{l}\text { - Employers liable to withhold PAYE on or after 1st April } 2020 \text { and } \\
\text { before 30th June } 2020\end{array}$ & & & \\
\hline & $\begin{array}{l}\text { - No interest or penalty on outstanding amount of tax during the same } \\
\text { period. }\end{array}$ & & & \\
\hline $\begin{array}{l}\text { Waiver of interest and penalty on } \\
\text { unpaid principal tax }\end{array}$ & $\begin{array}{l}\text { A taxpayer who makes any voluntary disclosure during the months of } \\
\text { March and April } 2020 \text { and pays the principal tax, shall have their } \\
\text { penalty and interest remitted in accordance with the law. }\end{array}$ & $\mathrm{N}$ & $\begin{array}{l}\text { Any penalty } \\
\text { outstanding as at } \\
\text { 30th June } 2020\end{array}$ & $\begin{array}{l}\text { Director, Tax and } \\
\text { Regulatory Services, } \\
\text { KPMG Uganda }\end{array}$ \\
\hline $\begin{array}{l}\text { VAT-Exemption of specified medical } \\
\text { supplies }\end{array}$ & $\begin{array}{l}\text { Exemption from VAT of supplies of specified medical goods used in } \\
\text { the prevention of the spread and the treatment of COVID-19 } \\
\text { pandemic }\end{array}$ & $\mathrm{N}$ & NA & KPMG Uganda \\
\hline $\begin{array}{l}\text { Excise duty exemptions on spirits for } \\
\text { manufacturing sanitizers }\end{array}$ & $\begin{array}{l}\text { Exemption from VAT of supplies of raw materials and inputs for the } \\
\text { manufacture of COVID-19-related items }\end{array}$ & $\mathrm{N}$ & NA & KPMG Uganda \\
\hline Tax Procedure Code-Act amendment & $\begin{array}{l}\text { The Bill proposes to defer tax payment dates to } 30 \text { September } 2020 \\
\text { for a taxpayer involved in the tourism, manufacturing, horticulture or } \\
\text { floriculture businesses with a turnover of less than UGX } 500 \text { million; or } \\
\text { one liable to a tax chargeable on employment income. } 30 \text { September } \\
2020 \text { for a taxpayer involved in the tourism, manufacturing, } \\
\text { horticulture or floriculture businesses with a turnover of less than } \\
\text { UGX500 million; or one liable to a tax chargeable on employment } \\
\text { income. }\end{array}$ & $\mathrm{N}$ & NA & KPMG Uganda \\
\hline $\begin{array}{l}\text { Supply of accommodation in tourist } \\
\text { lodges and hotels inside a radius of } \\
50 \mathrm{Km} \text { from the boundaries of Kampala }\end{array}$ & NA & $\mathrm{N}$ & $\begin{array}{l}\text { From 1st July } \\
\text { 2020- 30th June } \\
2021 .\end{array}$ & NA \\
\hline
\end{tabular}


Table D5: Tax-benefit policy measures in Zambia

\begin{tabular}{|c|c|c|c|c|}
\hline Name of policy measure & Description & $\begin{array}{l}\text { Policy modelled: } \\
\text { Y for yes, } \\
\text { N for no, } \\
\text { P for partially }\end{array}$ & $\begin{array}{l}\text { Duration of } \\
\text { measures }\end{array}$ & Source \\
\hline Emergency Cash Transfer & $\begin{array}{l}\text { Emergency social cash transfer to } \\
\text { households already receiving Social Cash } \\
\text { Transfer ('vertical expansion') and } \\
\text { expansion of the cash transfer to } \\
\text { vulnerable households working in informal } \\
\text { sector ('horizontal expansion'). Benefit } \\
\text { amounts } 400 \text { Kwachas per household per } \\
\text { month for } 6 \text { months. Programme covers } 22 \\
\text { districts. }\end{array}$ & $\begin{array}{l}\mathrm{P} \text {, only 'vertical } \\
\text { expansion' is } \\
\text { modelled }\end{array}$ & $\begin{array}{l}\text { From } 28 \text { July } 2020 \\
\text { (covers } 6 \text { months } \\
\text { and possible phase } \\
\text { approach, exact } \\
\text { timeline not known) }\end{array}$ & $\begin{array}{l}\text { Statement by the community development and } \\
\text { social services minister in the government's } \\
\text { launch of COVID-19 Emergency Cash Transfer } \\
\text { Programme on } 28 \text { July } 2020 \text { (other sources } \\
\text { include ZIPAR, UNICEF, MCDSS ) }\end{array}$ \\
\hline $\begin{array}{l}\text { Discontinuation of the Home- } \\
\text { Grown School Feeding } \\
\text { Programme }\end{array}$ & $\begin{array}{l}\text { The Home-Grown School Feeding } \\
\text { Programme was paused due to closure of } \\
\text { schools during lockdown }\end{array}$ & $\begin{array}{l}\text { Y, scaling the benefit } \\
\text { to cover only } 6 \\
\text { months in } 2020\end{array}$ & $\begin{array}{l}\text { From } 17 \text { March } 2020 \\
\text { to } 14-28 \text { September } \\
2020\end{array}$ & ZIPAR \\
\hline $\begin{array}{l}\text { Suspension of custom duties } \\
\text { and VAT on additional medical } \\
\text { supplies used in the fight } \\
\text { against COVID-19 }\end{array}$ & $\begin{array}{l}\text { In order to expedite the provision of } \\
\text { medical related devices needed to support } \\
\text { the fight against COVID-19, Government } \\
\text { will extend the list of medical supplies that } \\
\text { are not subject to import duty and value- } \\
\text { added tax for an initial period of } 6 \text { months. } \\
\text { The complete list comprises } 38 \text { individual } \\
\text { items which include testing equipment, } \\
\text { protective garments, thermometers, } \\
\text { disinfectants, sterilization products and } \\
\text { other medical equipment such as } \\
\text { ventilators and patient monitoring devices }\end{array}$ & $\begin{array}{l}\mathrm{N}, \text { no information of } \\
\text { item medical supplies } \\
\text { in MicroZAMOD }\end{array}$ & From April 2020 & $\begin{array}{l}\text { Statement by the finance minister on further } \\
\text { measures aimed at mitigating the impact of the } \\
\text { coronavirus on the Zambian economy }\end{array}$ \\
\hline $\begin{array}{l}\text { Waiver of tax penalties and } \\
\text { interest }\end{array}$ & $\begin{array}{l}\text { This is to assist companies and } \\
\text { businesses manage their cash flows during } \\
\text { the COVID-19 pandemic, when they are } \\
\text { faced with reduced revenues. The } \\
\text { government decided to waive tax penalties } \\
\text { and interest on outstanding tax liabilities } \\
\text { from the impact of COVID-19. }\end{array}$ & $\begin{array}{l}\mathrm{N}, \text { no tax penalties } \\
\text { and interest modelled } \\
\text { in MicroZAMOD tax } \\
\text { system }\end{array}$ & From April 2020 & $\begin{array}{l}\text { Statement by the finance minister on further } \\
\text { measures aimed at mitigating the impact of the } \\
\text { coronavirus on the Zambian economy }\end{array}$ \\
\hline
\end{tabular}




\section{Appendix E: Comparison of random allocation vs. transition method for Uganda}

Table E1: Impact of COVID-19 on mean incomes: random allocation method vs. transition method for Uganda

\begin{tabular}{|c|c|c|c|c|c|c|}
\hline & \multirow[b]{2}{*}{$\begin{array}{l}\text { Pre-crisis } \\
\text { scenario }\end{array}$} & \multirow[b]{2}{*}{ Crisis scenario } & \multirow[b]{2}{*}{$\begin{array}{l}\text { Total change (abs. } \\
\text { change) }\end{array}$} & \multirow[b]{2}{*}{$\begin{array}{l}\text { Income stabilization } \\
\text { coefficient }\end{array}$} & \multicolumn{2}{|c|}{$\begin{array}{l}\text { Decomposition of total change } \\
\text { (abs. change) }\end{array}$} \\
\hline & & & & & $\begin{array}{l}\text { Effect of automatic } \\
\text { stabilizers }\end{array}$ & $\begin{array}{c}\text { COVID-related reduction in } \\
\text { earnings }\end{array}$ \\
\hline & (A) & (B) & (C) & (D) & $(E)$ & $(F)$ \\
\hline Random allocation method & 747 & 705 & $-41.2^{\star \star \star}$ & 17.0 & +7.5 & -48.8 \\
\hline Transition method & 747 & 694 & $-52.6^{\star \star \star}$ & 16.4 & +8.5 & -61.2 \\
\hline
\end{tabular}

Note: the table presents estimates of the impact of the COVID-19 pandemic on mean incomes in Uganda in 2020, applying either the random allocation method or the transition method to allocate earnings shocks resulting from COVID-19. Columns (A) and (B) show mean disposable incomes in the scenarios without and with shocks from COVID-19. Amounts are given in international dollars and derived based on harmonized equivalence scales. Column (C) shows the overall impact of the crisis as an absolute change in mean incomes (B-A). Column (D) shows the income stabilization coefficient. Columns (E) and (F) show the effects of automatic stabilization of the tax-benefit system and the COVID-related earnings shock $(C=E+F)$. The changes in column $(C)$ include statistical significance based on bootstrapped standard errors after 200 replications. Significance levels indicated as * $p<0.1,{ }^{* *} p<0.05$, ${ }^{* *} p<0.01$.

Source: authors' elaboration using UGAMOD, the tax-benefit microsimulation model for Uganda, the Uganda National Household Survey (UNHS), 2016-2017, and World Bank High-Frequency Phone Surveys in Uganda 2020. 
Table E2: Impact of COVID-19 on poverty and inequality: random allocation method vs. transition method

Pre-crisis scenario

Poverty rate, FGT(0)

Random allocation method

Poverty gap, FGT(1)

Gini coefficient

Poverty rate, FGT(0)

Transition method
(A)

71.40

Crisis scenario

(B)

72.80

49.91

66.54

66.52

71.40

48.66

66.52

49.78

65.92
Total change (pp.)

(C)

$+1.40^{* \star *}$

$+1.25^{\star \star \star}$

$+0.02$

$+1.51^{\star \star \star}$

$+1.12^{\star \star \star}$

$-0.60^{\star \star *}$
Total change (\%)

(D)

$+2.0 \%$

$+2.6 \%$

$+0.0 \%$

$+2.1 \%$
$+2.3 \%$

$-0.9 \%$

Note: the table presents estimates of the impact of the COVID-19 pandemic on measures of poverty and inequality in Uganda in 2020 , applying either the random allocation method or the transition method to allocate earnings shocks resulting from COVID-19. Columns (A) and (B) show the poverty rate, poverty gap and Gini coefficient in the scenarios without and with shocks from COVID-19. Outcomes are derived based on harmonized equivalence scales and a standard international poverty line (disposable income under US\$1.9 per day). Column (C) and (D) show the overall impact of the crisis as a percentage point change and percentage change, respectively. Statistical

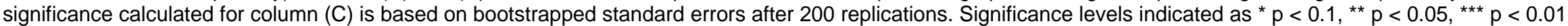

Source: authors' elaboration using UGAMOD, the tax-benefit microsimulation model for Uganda, the Uganda National Household Survey (UNHS), 2016-2017, and World Bank High-Frequency Phone Surveys in Uganda 2020. 